\title{
Explaining Regional and Local Government An Empirical Test of the Decentralization Theorem
}

\begin{abstract}
Decentralization of policy provision is omnipresent yet we are not able to sufficiently account for the extent of this phenomenon. The decentralization theorem explains the decentralization of policy provision as a trade-off between heterogeneous preferences, inter-jurisdictional spillovers (externalities) and economies of scale. Empirical tests of the theorem have been hampered by a measurement problem on the independent as well as on the dependent variable. This article tackles these problems by using a new dataset which combines a measure of externalities and scale effects of policies obtained from an expert survey with the actual provision of policies across governmental tiers in 40 countries. The analyses show that decentralization of policy provision is not solely determined by functional characteristics of policies but that heterogeneous preferences and other country specific variables such as democracy, economic development and European subsidies, also play a significant role. Hence, this article provides an empirical test of the decentralization theorem.
\end{abstract}

Presented at 11th Biennial International Conference of the European Union Studies Association, Los Angeles, California * April 23-25, 2009

Arjan H. Schakel

PhD-candidate

Political Science Department

Vrije Universiteit Amsterdam

De Boelelaan 1081c

1081 HV Amsterdam

e-mail: ah.schakel@fsw.vu.nl 


\section{Introduction}

Virtually no central government during modern history has provided and implemented policies on its own. Even the tiny states of Malta and Luxembourg have two levels of government. ${ }^{1}$ In theory, multilevel government should be common, yet, few theories have been rigorously tested. The predominant approach is summarized by the 'decentralization theorem' (Oates 1972; Bolton and Roland 1997; Alesina and Spolaore 2003; Osterkamp and Eller 2003; Breuss and Eller 2004, Stegarescu 2005). This theorem states that the optimal degree of decentralization depends on the heterogeneity of preferences, on the one hand, and inter-jurisdictional spillovers (externalities) and economies of scale, on the other hand (Alesina and Spoalore 2003; Oates 1972 and 1999). An externality or spill-over arises when a decision produces costs or benefits to people other than those making the decision (Tullock 1969). Scale effects occur when additional units of a good or a service can be produced with relatively less input costs (Tullock 1969).

The externalities and scale effects of most policies provided by government-e.g. health, education, economic development, spatial planning, environment and welfare services-are such that they require some degree of decentralization coupled with some centralized coordination (Shah 2006 and Ahmad, Hewitt, and Ruggiero 1997). Hence, multilevel government should be very common (see also Hooghe and Marks 2001). However, clear recommendations for the practical assignment of policy tasks is hampered by tensions created by the trade-off between the realization of scale effects and the internalization of externalities, on the one hand, and the consideration of local preferences, on the other hand (Breuss and Eller 2004, 41). The normative

\footnotetext{
${ }^{1}$ Andorra and San Marino have only one level of government, but the citizens in those states are (partly) reliant on policy provision by the French and Spanish, respectively the Italian governments.
} 
recommendation is further fettered by country-specific factors, such as politicoeconomical variables, which should also be taken into account (Breuss and Eller 2004). Therefore, to examine whether countries follow the normative considerations of the decentralization theorem requires an empirical and case-by-case analysis (Breuss and Eller 2004). Such an analysis, however, is complicated by measurement problems. First, the dependent variable-allocation of policy provision tasks over governmental tiers-is difficult to measure (Oates 1972; Page 1991; Treisman 2007, 26-27). As Wallace Oates $(1972,196)$ and Edward Page $(1991,14)$ note, a direct measure requires a list of public goods provided by each level of government in each country.

Second, empirical analysis requires measurement of externalities and scale effects but it is difficult to make unequivocal statements concerning which governmental tier should provide a policy. For example, Teresa Ter-Minassian (1997a) argues convincingly that primary education should be provided, at least partially, by local governments and that defense should be a national responsibility. However, to claim that primary education is (always) best provided by a jurisdiction with a population size of about 20,000 people is problematic. Even if one knows how preferences are distributed over jurisdictions it is still a very challenging task to determine which jurisdictional size optimizes internalization of externalities and scale effects.

This article tackles both problems by using a new dataset which combines a measure on externalities and scale effects of policies obtained from an expert survey with the actual provision of policies by governmental tiers in 40 countries obtained from detailed country studies by the Council of Europe and Local Government and Public Reform Initiative. Empirical analysis of the dataset provides evidence that countries do indeed follow patterns predicted by the decentralization theorem. That is, 
the allocation of policy provision tasks over governmental tiers is indeed a result of externalities and scale effects associated with policies and local preferences.

The article is organized as follows: the next section summarizes the hypotheses posed in the literature to explain jurisdictional policy provision. The subsequent section deals with the data, operationalization of the variables and methodological issues. Then the results are reported which are followed by concluding remarks.

\section{Hypotheses}

This section summarizes expectations concerning when to expect local, regional and national policy provision. According to the decentralization theorem externalities and scale effects associated with policies and local preferences should play a role but also other country-specific factors like politico-economical variables. Three countryspecific factors are discerned: level of democracy, economic welfare and European Union membership. The hypothesized causes of multilevel policy provision are subsequently dealt with.

\section{Externalities and scale effects}

The two most important characteristics of public goods are externalities and scale effects (Besley and Coate 2003, 2628). The optimal jurisdictional size from a functional perspective is the one which internalizes externalities and reaps benefits of scale. It is important to note that in this perspective each policy has its own optimal jurisdictional size. ${ }^{2}$ Deviations from functionality arise when local preferences are

\footnotetext{
${ }^{2}$ Another functional characteristic are scope effects/transactions costs which, however, are not policy specific. Scope effects arise when multiple policies are provided by the same governmental tier at lower relative costs compared when each policy is provided by different governmental tiers. This cost reduction is a result of reduced transaction costs and/or internalization of spillovers between policies.
} 
heterogeneous. Optimality in the perspective of the decentralization theorem concerns the trade-off between functionality and heterogeneous preferences. In this article, however, a measure of functional optimal jurisdictional size is used and deviations from this pattern will be explained by the hypotheses posited below.

\section{Local Preferences}

Different local preferences regarding public goods may lead to decentralized policy provision. Geographical diversity in tastes for public services can be especially expected when ethnic-cultural-language-regional identities differ (Oates 1972; Alesina and Spolaore 2003). Individuals with different ethnocultural traditions may desire heterogeneous mixes of public goods, such as education, welfare and economic policy (see for empirical evidence: Osterkamp and Eller 2003).

Also, individuals sharing ethnocultural norms may desire self-rule on intrinsic grounds leading to a demand for decentralized policy provision (Duchacek 1970; Page and Goldsmith 1989; Keating 1998; Loughlin 2001). Autonomy demands are usually mediated by political mobilization, e.g. by regionalist parties which demand decentralization (Brancati 2005 and 2006; De Winter and Gomez-Reino Cachafeiro 2002; Sharpe 1993; Urwin 1985; Rokkan 1999; Rokkan and Urwin 1983). It is therefore expected that-to the extent that ethnic/regional minorities are politically mobilized-the relationship between local preferences and decentralized policy provision strengthens.

Decentralization might also result from differences in, for example, economic or ideological preferences. Alesina and Spolaore (2003) argue that democratization makes the political system more responsive to heterogeneous preferences. The authors

Scope effects/ transaction costs may have great explanatory power with regard to the number and type of subnational tiers as it is more economically efficient and effective to establish two or three generalpurpose subnational tiers than several specific-purpose governmental tiers (Hooghe and Marks 2003). 
are indifferent regarding the source of heterogeneity of policy preferences which, thus, can have multiple roots. In order to test the argument made by Alesina and Spolaore, the model below introduces the variable general preferences which is measured by the Vanhanen index. This index consists of two components: competition and participation. Competition indicates the degree of power sharing among political parties (Vanhanen 2000, 253). The degree of participation indicates the extent of 'the people' taking part in politics, i.e. the extent of 'direct democracy' (Vanhanen 2000, 253). When all power is in the hands of one political party and hardly any people are eligible to vote, more central government concentration of policy provision is to be expected.

\section{Country-specific variables: democracy, economic development and}

\section{European integration}

It is hypothesized that authoritarianism leads to deconcentrated rather than decentralized policy provision. Treisman $(2007,40-2)$ identifies two views of the link between authoritarian regimes and decentralization. The first is that authoritarian leaders impose whatever policy they like, limited only by functional and economical pressures. A second view sees authoritarian rulers as constrained, although in different ways than democratic politicians. An authoritarian regime also needs support of a substantial number of its citizens and one way to achieve this may be decentralizing policy provision according to local preferences. The result of both causal processes, however, is deconcentration rather than decentralization; that is, in authoritarian regimes policies are provided by central government agents rather than by locally elected politicians. 
It is expected that economically affluent countries make more use of decentralized policy provision than less developed countries. Some scholars note that economic development, not democracy per se, may explain the association between decentralization and democracy (Treisman 2002; Prud'homme 1995). Economic development might make decentralization of policy provision to subnational tiers affordable (Wheare 1963, 51; Oates 1972, 228-229). Another explanation is that it is only at relatively high levels of per capita income that decentralization is demanded by citizens in the sense that its benefits can be more fully exploited without the problems or disadvantages that tend to be more present in countries at lower levels of development (Bahl 1999; Bardhan 2002; Martinez-Vazquez and McNab 2003).

A final hypothesized cause of decentralization is the process of European integration. Three causal paths are put forward. First, subnational tiers are likely to seek access to EU decision-making processes in those cases where EU policies cut across their domestic competence base (Jeffery 2000). This development might have led to a shift of decision-making power to the advantage of subnational tiers.

Second, European integration leads to an increase in economic viability of regions which subsequently results in subnational mobilization. European integration removes large barriers to trade diminishing the economic advantage of large state size and, at the same time, increasing the prosperity of small countries and large regions (Alesina and Spolaore 2003; Marks and Hooghe 2000). Therefore, the decentralization demand of subnational actors is made more realistic and more politically influential by European integration (Jolly 2006 and 2007).

A third hypothesized causal path concerns the instrument of EU-funding which is thought to enhance subnational mobilization as the EU distributes money directly to subnational governments (Jeffery 2000; Marks, Salk, Ray, Nielson 1996; Hooghe and 
Marks 2001). Furthermore, EU-funding pressures national governments to empower subnational authorities in EU cohesion policy (Brusis 2002; Hooghe 1996). Consequently, EU-subsidies might also lead to decentralized policy provision.

\section{Data, Operationalization and Method}

\section{Expert survey and country studies}

To derive measures for functional characteristics of policies, I use an expert survey conducted by Liesbet Hooghe, Gary Marks and Arjan H. Schakel in which 36 policy experts indicate for 34 policies which jurisdiction should have a role in provision considering only scale effects and externalities (appendix A). ${ }^{3}$ From the expert survey an externalities and scale effects variable for each tier is constructed and these are operationalized as the probability that an expert would place an $X$ in that jurisdiction for a given policy. The variable externalities and scale effects measures the probability that tier $A$ in country $B$ has a role in the provision of policy $C$. As mentioned above, this variable is used as a measure of optimal jurisdictional size from a functional perspective. An example is given below.

\footnotetext{
${ }^{3}$ The question remains whether the expert survey solves the conceptual problems of measuring externalities and scale effects. I do not know whether the expert survey sufficiently solves these problems simply because we do not have a 'golden standard' of how to measure functional/economic characteristics of policies. For example, Dear, Fincher and Curie (1977) used psychometric methods to measure intangible external effects as perceived by citizens of public programs such as locational decisions of a landfill or mental health facility. Another study (Weigher and Zerbst 1973) measured externalities of neighborhood parks by comparing house prices of houses adjacent to a park with houses one block away from the park to determine whether public provision of these parks is economically justified. Price differentials are often used to quantify externalities (e.g. Le Goffe 2000; Irwin and Bockstael 2001; Eshet, Baron, Shechter and Ayalon 2007) but these studies do not investigate the scale-in area and population size-in which externalities occur.

Other studies which have looked at the optimal distribution of competencies across levels of government are in essence expert judgment themselves (Alesina, Angeloni and Schuknecht 2005; Breuss and Eller 2004). Two major advantages of the expert survey in this article are, first, that I use more expert judgments than previous attempts which allows me to assess reliability. Second, the design of the expert survey allows me to assess validity concerning structural error as well. In addition, Shah's (1997) analysis is used to validate the expert survey (see appendix A).
} 
The expert survey data is matched with data on the actual policy provision by governmental tiers in 40 countries, i.e. 16 West-European, 15 Central and Eastern European and 9 Caucasian republics. This data is collected by combining country studies undertaken by the Council of Europe and The Local Government and Public Service Reform Initiative (appendix B). The country studies provide information on policy provision for 34 policies which coincide with the policies used in the expert survey.

The country studies indicate whether a particular tier has a role in policy provision but the roles are not clearly specified in terms of depth and scope. First, the role of a tier may range from autonomous decision-making on policies to implementation according to strict central guidelines. Unfortunately, the country studies do not differentiate between regulation and executive powers. Second, the dependent variable does not provide information on the scope of the role either as it is not possible to discern the precise division of tasks between tiers. For example, when a policy is performed at the local as well as the regional level one does not know whether the division of tasks between these tiers is $30-70 \%$ or $70-30 \%$, etc. What one can argue, however, is that when the national, regional and local tier co-provide the policy the country is more decentralized than in the case when the national government solely provides the policy.

The dependent variable is operationalized as a multinomial variable to account for the fact that the extent of decentralization cannot be discerned. That is, the data may indicate that decentralization has taken place, but it does not allow me to discern with respect to the depth (decision-making versus implementation powers) or scope (finance, infrastructure, personnel, etc.) of decentralization. 
However, the operationalization of the dependent variable does not affect the empirical test of the decentralization theorem. The decentralization theorem states that policies should be adapted towards heterogeneous preferences and decentralization is an instrument to achieve this in an optimal manner. But the decentralization theorem does not say anything about the required depth or scope of decentralization. As Treisman notes $(2007,11)$ "an all-powerful central government, implementing [policies] via subordinate field agents, could achieve the same efficiencies".

In this article I am interested in the question when policy tasks are decentralized to tiers where heterogeneous preferences have or are likely to have influence on policy implementation. A centrally appointed executive, who is responsible to the national government only, can relatively easily neglect heterogeneous preferences. Therefore, I include only tiers where 'voice' is organized, that is, tiers with a parliament, assembly or council. $^{4}$

Some countries combine deconcentration with self-governance at the same governmental tier either by creating separate administrations (Denmark, France, Norway, Romania, and Sweden) or by a centrally appointed executive head (Albania, Belgium, Lithuania, Poland, and the Netherlands). These governmental levels are included as some of these countries elect representatives in the executive of the deconcentrated state administration and/or the executive head is responsible to the

\footnotetext{
${ }^{4}$ When policy provision is the responsibility of the national government it does not mean that the national government can or does not recognize, for example, heterogeneous preferences. The national government may decentralize policy provision via deconcentrated agencies which might adapt policies according to heterogeneous preferences as even with delegation there is some room for influencing policy implementation (see e.g. Lipsky 1983; Meyers and Vorsanger 2003; Scott 1997; Sowa and Coleman Selden 2003). Austria and Serbia (within Serbia and Montenegro) are examples of countries which make use of general-purpose deconcentrated state administrations without councils or assemblies. An appendix, available from the author upon request, shows whether the national government makes use of deconcentrated general-purpose agencies and/or other deconcentrated state agencies. It turns out that all countries make use of deconcentrated policy provision although in a different manner (i.e. via general purpose state administration and/or deconcentrated agencies arranged per ministry) and to a different extent. In this way, the influence of voice is not guaranteed and it is left to the head of the deconcentrated agency or a national ministry to recognize heterogeneous preferences in the decision how, where and when to provide the policy.
} 
council with respect to the deconcentrated tasks (Belgium, Denmark, Luxembourg, the Netherlands, and Sweden). In other countries the policy portfolio of the deconcentrated state administration is rather limited (France, Norway, Poland, and Romania). In Albania and Lithuania, the executive heads are centrally appointed but there is an advisory council present. The Caucasian republics make extensive use of centrally appointed executives which are under strict central government control. These subnational tiers are still included as long as there is an advisory council present. The model analyzed in this article introduces a variable which controls for the extent of democracy within a country.

To summarize, the dependent variable indicates whether a particular tier or a combination of tiers, where 'voice' is organized, has a role in policy implementation. More details on the country studies are provided in appendix B.

\section{Data structure}

The process of matching the expert survey with the country study data is displayed in tables $1 \mathrm{~A}$ and $1 \mathrm{~B}$. The first column of table $1 \mathrm{~A}$ shows five jurisdictional sizes as used in the expert survey. The column 'experts' presents the probabilities that an expert will put an $X$ in that jurisdiction for a given policy. The probability is taken as a proxy that the jurisdiction has a role in providing the policy when only externalities and scale effects are considered. The sum of probabilities over five jurisdictions is 1 .

[Tables 1A and 1B about here]

The next columns represent the country data. For each local, regional and national tier of a country an average population size is calculated (data on population size is obtained from the country studies and www.statoids.com, last consulted on August 20, 2007). A tier of a country is first classified into the jurisdictional scales used in the 
expert survey. Subsequently, it is determined whether this tier has a role in providing the policy. Finally, the outcome category is established which is matched to the probabilities from the expert survey. The resulting data structure is presented in table $1 \mathrm{~B}$.

To give an example, in country A, the national, the regional as well as the local tier provide the policy which results in the outcome category NRL. This outcome category constitutes the dependent variable while the probabilities from the expert survey are used as independent variables. For country A this means that the outcome category NRL is matched with probability National tier $=0.4$; probability Regional tier $=0.2$ and probability Local tier $=0.1$. For country $\mathrm{C}$ this means that outcome category $\mathrm{N}$ is made dependent upon probability National tier $=0.2$ and probability Local tier $=0.1$. This is repeated for 40 countries and 34 policies.

\section{Controls: ceiling effect and multilevelness}

To analyze the data, it is necessary to control for two policy-specific functional characteristics. In this section I argue that one should control for country size and the 'multilevelness' of policies.

Country D exemplifies why one should correct for country size. The population size of country D is about one million and therefore probability National tier $=0.2$. According to the experts-who only take externalities and scale effects into consideration-country $\mathrm{D}$ would do a better job when the policy is provided by a jurisdiction of about five million people. To conclude that country D deviates from the pattern predicted by externalities and scale effects would be incorrect. Country D cannot 'push the policy up' to larger jurisdictions and is therefore not able to provide the policy more efficiently. The best country D can do is to provide the policy through 
the national tier. As a consequence, more policies will be provided by the national tier of country D than the regional tiers in country A and country B despite the fact that they all have approximately the same population size. To correct for this, the variable ceiling effect is introduced and is operationalized as the sum of the probabilities assigned to the jurisdictions scales larger than the country. For country D this means a value of 0.6 for the ceiling effect. Country A scores 0.2 on the ceiling effect, whereas countries B and C score 0.0 (see table 1B). The variable ceiling effect varies over countries and policies.

A second functional characteristic of policies is the 'multilevelness' of policies. So far I have assumed that each policy has its own optimal jurisdictional size. However, some policies, such as environmental protection and roads, are efficiently handled by multiple jurisdictions and experts place $X^{\prime}$ s at multiple jurisdictional scales. To correct for the degree of 'multilevelness', the variable multilevel is introduced into the model and this variable is operationalized as the total number of placed $X$ 's by the experts per policy. This variable varies over policies only (see appendix A).

\section{Model}

Table 2 summarizes the operationalization of the independent variables introduced in the model. Appendix C provides statistical information on the independent variables. ${ }^{5}$

\section{[Table 2 about here]}

Multinomial logit regression analysis is a suitable analytical technique as the outcome categories constitute a multinomial variable. ${ }^{6}$ In this type of analysis,

\footnotetext{
${ }^{5}$ From the Pearson correlation table in appendix $\mathrm{C}$ (table $\mathrm{C} 2$ ) one can see that the general preferences and polyarchy variables correlate highly (i.e. Pearson correlation $>0.77$ ). Despite this multicolinearity, however, the results appear to be robust, i.e. the estimations do not significantly change when general preferences or polyarchy is excluded.

${ }^{6}$ A potential weakness of the multinomial model is the independence of irrelevant alternatives (IIA) assumption. IIA means that the ratio of the categorical probabilities for two alternatives, A and B, is
} 
probabilities of policy provision by the different tiers and combinations of tiers can be calculated without making any assumption on the rank order or intervals of the different categories. Robust standard errors are used as policies are clustered within countries. $^{7}$

\section{Results}

The results of the multinomial logit regression analysis for twenty-six three-tier countries are given in table $3 .^{8}$ The national tier is taken as a base category and is compared to the six other outcome categories.

\section{[Table 3 about here]}

The functional variables have their hypothesized effect. An increase in the probability that the national tier provides a policy (probability National tier) coincides with a decrease in the probability that the regional or local tier, or the national tier in combination with the local or regional tier, provide the policy. The local tier gains a role in policy implementation, at the expense of the national tier, when probability Local tier increases. In smaller countries, the national tier gains role in policy provision whereas the regional and local tier combined loose role (ceiling effect). Finally, policies which should be provided by multiple tiers are indeed more often provided by combinations of tiers than by the national tier solely (multilevel).

independent from all other alternatives in the categorical set (see Long 1997). I compute Hausmann and Small-Hsiao test statistics for both the three-tier and two-tier country dataset which suggests that the IIA assumption is not violated.

${ }^{7}$ Robust standard errors cannot be estimated while simultaneously correcting for clustering of policies within countries and countries within policies. The results reported are robust when policies clustered instead of country clustered robust standard errors are used.

${ }^{8}$ Here I examine three-tier countries, however, the results reported are robust when examined in a two-tier format (see appendix B). 
A remarkable finding in table 3 is that most other independent variables do not seem to have a significant effect. Though, those variables that do have a significant effect support the hypotheses. Ethnic fragmentation leads to more combined policy provision by the national plus regional or regional plus local tiers. Economic development leads to more policy implementation by the local and national tier whereas European subsidies lead to more role in policy provision for the national tier combined with the regional tier. These results might be interpreted as decentralization because these outcome categories gain role compared to the probability that the national tier solely provides a policy. However, we may also speak of decentralization when, for example, the regional and local tier combined gain role at the same time when the national, regional and local tier combined loose role. To investigate this possibility I need to change the base category: instead of using policy provision by the national tier solely I should use policy provision by the national + regional + local tier.

As each outcome category may be compared to each other outcome category for all independent variables, the amount of the number of comparisons increases significantly (i.e. for the three-tier countries: 7 x 6 category outcome comparisons $\mathrm{x}$ 12 independent variables). To enhance interpretation and reduce complexity, only the number and signs of the significant beta coefficients are given in table 4 and the size of beta-coefficients are left aside for the moment as these cannot be summed (Long 1997).

\section{[Table 4 about here]}

The column 'national tier' shows the results when the national tier is the base category. The results presented in the row probability National tier in table 3 are summarized in one cell of table 4 . An increase in the probability that the national tier 
provides a policy (probability National tier) coincides with a decrease in probability for five outcome categories (table 3). This means that the probability that the national tier solely implements a policy increases to the expense of the probabilities of five other outcome categories; hence the +5 in the first cell of table 4 . This is repeated for each outcome category. In each row of table 4 the total number of ' + ' and '-' is equal. When a ' + ' and ' - ' are combined in one cell it means that an increase in the independent variable leads to a higher and a lower probability for the base category depending to which other outcome category one compares.

By presenting the positive beta coefficients in bold, tendencies of policy provision across categories becomes apparent. A higher probability National tier, for example, leads to a gain in policy provision by the national tier only and a combination of the national, regional and local tiers. Conversely, a higher probability National tier leads to a reduced role in policy provision by the regional and local government alone and by the combinations national plus local and regional plus local tiers. Similar interpretations account for probability Regional tier and probability Local tier. For all three tiers, these probability variables have their hypothesized effect.

The ceiling effect leads to a higher probability that the national tier will be involved in policy provision whereas the regional and local tier combined obtain a lower probability. The multilevel variable has also its hypothesized effect as the probabilities of policy provision by the national, regional or local tier only decreases, whereas the probabilities of policy provision by combinations of tiers increases.

The combined effect of ethnic fragmentation and the strength of the ethnoregional parties lead to a higher probability that the regional tier and, to a lesser extent, the local tier has a role in policy provision. Ethnic fragmentation leads to more policy provision by the regional tier alone or any combination in which the regional tier is 
part of. Political mobilization of ethnoregional minorities lead to higher probabilities of policy provision by the national and regional tier combined and the local tier in combination with the regional tier. Although the probabilities that the national tier and local tier will have a role in policy provision decreases when ethnic fragmentation increases, once the ethnoregional minorities are politically mobilized, the probability that national and local government gains a role in policy provision increases. Though, the gain for the national tier seems to be offset when preferences in general are politically mobilized. An increase in general preferences leads to a decrease in the probability of co-provision by the national plus regional and regional plus local tier and by a combination of all three tiers whereas the probability of policy provision by the local or regional tier only increases. In sum, however, heterogeneous preferences lead to decentralization of policy provision.

The country-specific variables show centralizing and decentralizing trends. Contrary to expectations democracy leads to centralized policy provision as the local tier loose and the national tier gains role. Polyarchy increases policy provision by the national plus regional tier and leads to less policy provision by the local or regional tier only or by all three tiers combined.

Development leads to decentralized policy provision as economic welfare decreases the probability that the national tier solely provides the policy and increases the probability that policies are co-provided by the national and local or all three tiers together. However, development also leads to less provision by the local tier solely which signifies some centralizing tendency.

Finally, EU-membership seems to have no bearing at all on which governmental tiers provide the policy, but EU-subsidies have. When a country receives EUsubsidies, the probability that a policy is provided by a local tier decreases. The 
probability of policy provision by the local tier solely, by a combination of the national and local tier or by a combination of the regional and local tier decreases which is probably not offset by the increase in the probability of policy provision by all three tiers together. The regional and, to a lesser extent, the national tier seem to get a higher probability of being involved in policy provision as the increase in the probability that a combination of the national and regional tier and/or all three tiers co-providing the policy probably makes up for and more the loss in probability for the national tier only, a combination of the national and local tier and the combination of the regional and local tier. EU-subsidies have thus also a decentralizing and a centralizing effect.

How may one explain the decentralizing and centralizing influence of the countryspecific variables? If one focus on the combined effect of the country-specific variables, one can see in table 4 that the probabilities that policies are implemented by tiers on their own decrease whereas the probabilities that a combination of tiers have a role in policy provision increase. The country-specific variables, apparently, do not have clear decentralizing or centralizing effects but they do lead to more multilevel government. Closer examination reveals that these variables pit the Caucasian republics and the eastern European countries ${ }^{9}$ against the western European countries. The Caucasian republics and the eastern European countries are not a member of the EU (before 2002) and score significantly lower ( $<$ 0.05; ANOVA) on democracy, economic development and general preferences but not on the other independent variables. The need for multilevel government may increase when citizens become

\footnotetext{
9 Albania, Belarus, Bosnia and Herzegovina, Croatia, Hungary, Kazakhstan, Latvia, Lithuania, Moldova, Poland, Romania, Russian federation, Serbia and Montenegro, Ukraine and Uzbekistan.
} 
more involved in politics and economies become more developed, interdependent and integrated.

The results presented in table 4 shows that all independent variables, except $E U-$ membership, have a bearing on which governmental tier or combination of tiers provides a policy. To assess the contribution of the independent variables in explaining policy provision, table 5 presents the improvement of the model measured by two different pseudo- $\mathrm{R}^{2 \text {, }}$ s. First, a model with the functional independent variables is estimated and each cluster of independent variables is subsequently introduced into the model.

\section{[Table 5 about here]}

From table 5 one can observe that most of the improvement can be ascribed to the functional and preference clusters of independent variables which account for approximately two-thirds and one-fourth, respectively, of the total improvement. The addition of the democracy, development and EU-integration variables do add some significant improvement of the model but the improvement is small. This seems to suggest that policy provision by governmental tiers is largely shaped by functional characteristics of policies and the presence of heterogeneous preferences. The results does not depend on the number of independent variables included per cluster as the results for the adjusted McFadden's pseudo- $\mathrm{R}^{2}$, which adjusts for the number of parameters in the model, corroborate the results for the Cox\&Snell pseudo- $\mathrm{R}^{2}$.

In order to gauge which outcome categories are affected, changes in predicted probabilities are calculated. Shown in figure 1 are the changes in predicted probabilities for the seven outcome categories in the 26 three-tier countries when the independent variables of the preference cluster increase with one standard deviation 
while all other independent variables are held at their mean. Figure 1 displays the effects of preferences relating to identity (i.e. ethnic fragmentation and strength of ethnoregional parties) separately from those resulting from heterogeneity of general preferences (general preferences) as these variables affect outcome categories in different and opposing ways (see table 4).

\section{[figure 1 about here]}

From figure 1 the differential effect of identity and general heterogeneous preferences becomes clear. When ethnoregional minorities are present and become politically mobilized, the national and local tier loose role while the regional tier gains role in policy provision. The probability that policy provision by the national and local tier solely and in combination decreases while the probabilities for national plus regional tier and regional plus local tier increases. General preferences, however, increases the probability that the local tier solely provides the policy but the national and regional tier loose role as the probability that policies are provided by the national combined with the regional tier or all three tiers together decreases. All variables have their hypothesized decentralizing effect, but in case of identity the regional tier seems to gain role whereas for general preferences it is the local tier which gains role.

How can one account for this differential effect? A closer examination on the data reveals an interesting pattern. General preferences is negatively correlated with ethnic fragmentation (Pearson $r ;-0.39 ; \mathrm{p}<0.05$ ). If we look at the countries which score high on democratic openness but low on ethnic fragmentation we observe that the Scandinavian countries (Denmark, Finland, Norway and Sweden) are pitted against the other countries. Indeed, Scandinavian countries score significantly higher on general preferences (36.7 versus 25.5) and lower on ethnic fragmentation $(0.137$ 
versus 0.370$)$ but not on the other independent variables $\left(\mathrm{p}<0.05\right.$; ANOVA). ${ }^{10}$ If we calculate the proportion of policies which are provided by the local tier solely out of total policies we find a striking average of $52 \%$ for the Scandinavian countries versus $24 \%$ for the other countries ( $p<0.05$; ANOVA).

A difference in ideological preferences between countries may explain this finding. Political scientists often group the Scandinavian countries together with respect to the form of political organization and in terms of central-local relations. The vertical state structure of Scandinavian countries may be described as decentralized unitary countries with strong local autonomy (Page and Goldsmith 1987; Loughlin 2001). The evolution of this state format might be explained by the growth of the welfare state. The scale effects and externalities of educational, social welfare and health policies are such that implementation needs to be decentralized (Ter-minassian 1997b) and as the Scandinavian countries have a long standing tradition of local democracy combined with social democratic hegemony during the last five decades (Huber and Stephens 2001), local governments have been strengthened at the same time as the welfare state was developed.

Changes in predicted probabilities for the other three clusters (democracy, development and EU-integration) are also calculated but do not reach significance except for two outcome categories. A standard deviation increase in polyarchy leads to less policy provision by the regional and local tier combined (about $-7.0 \%$ ) and EU-integration leads to a lower probability that the local tier solely provides a policy (about $-10.0 \%$ ). These results corroborate the conclusion that policy provision is, by and large, a result of a trade-off between functionality and heterogeneous preferences.

\footnotetext{
${ }^{10}$ The Scandinavian countries also score significantly higher on economic welfare but an increase of one standard deviation in economic welfare, while all other variables are held at their mean, has no significant effect.
} 


\section{Concluding remarks}

This article shows that policy provision is determined by policy characteristics, on the one hand, and local preferences and country-specific factors, on the other. Countries seem to follow the recommendations of the decentralization theorem. Functional characteristics, preferences, democracy, European subsidies and economic welfare all have a bearing on which particular tier or combinations of tiers will provide a policy although the strength of these factors varies considerably. The real added value of this article, however, is to show that these effects hold while controlling for the other independent variables and thus providing a systematic empirical test of the decentralization theorem.

The results show that heterogeneous preferences lead to decentralization of policy provision. First, a difference in ideological preferences between countries may explain the decentralization of policies to local governments in the Scandinavian countries. An increase in heterogeneity of general preferences leads to policy provision by the local tier. Second, heterogeneous preferences with respect to identity increase the probability that the regional tier is involved in providing policies whereas the probability for the national and local tier decreases. This means that, in the perspective of the national government, the presence of ethnoregional minorities and the political mobilization of these minorities, leads to decentralization of policy provision. However, from the viewpoint of local governments it means centralization (see also Toonen and Steen 2008).

The other independent variables show centralizing and decentralizing results, but their overall effect is that the probability that policies are solely provided decreases whereas the probability that multiple tiers have a role in policy implementation 
increases. Democracy, economic development and European integration may lead to more multilevel government.

The results exemplify that centralization and decentralization should be conceived as concentration, respectively, diffusion or sharing of authority rather than 'closer to or away from the national government' as it is normally understood (e.g. Oates 1972; Page and Goldsmith 1989; Treisman 2007; Watts 2008). Decentralization is better conceived as sharing of authority over multiple tiers whereas centralization should denote concentration of authority at a particular tier which scale might range from the local to the global.

In my view, there are three interesting avenues for further empirical research on the decentralization theorem. As the dependent variable concerns tiers where 'voice' is present, it is useful to complement the dataset with data on policy provision by general purpose deconcentrated state agencies or deconcentrated state agencies arranged per ministry.

Another promising line of research is to increase the number of policies and to investigate policy specific effects. Policies like defense and foreign relations are always provided by the national government, whereas other policies, like garbage collection, are most often provided by local governments. The externalities and scale effects of those policies are so intense that deviation from the functional optimal jurisdictional size is (very) costly. A policy specific hypothesis would then be that the probability for a policy to be decentralized is dependent upon the intensity of its externalities and scale effects or that social-cultural policies have a higher probability to be decentralized than other policies as it may be expected that ethnic minorities will prioritize having autonomy over these policies. 
Finally, increasing the informative nature of the data deserves attention. The dependent variable used in this article is a simple dichotomous variable which varies over outcome categories. It is very difficult to tell what is behind the zeros or ones in terms of depth and scope. A one may range from autonomous decision-making on policies to implementation according to strict central guidelines. In terms of authority, these two possible situations constitute extremes. Also, it would be interesting to see when policies are shared, i.e. when multiple tiers score a one, to measure which tier is responsible for finance, personnel, redistribution, infrastructure, etc. 


\section{References}

Ahmad, Ehtisham, Daniel Hewitt and Edgardo Ruggiero. 1997. "Assigning Expenditure Responsibilities." In Fiscal Federalism in Theory and Practice, ed. Teresa TerMinassian. Washington: International Monetary Fund, 25-48.

Alesina, Alberto and Enrico Spaolore. 2003. The Size of Nations. Cambridge: MIT Press.

Alesina, Alberto, Ignazio Angeloni and Ludger Schuknecht. 2005. "What does the European Union do?" Public Choice, 123 (3/4): 275-319.

Annett, Anthony. 2001. "Social Fractionalization, Political Instability, and the Size of Government." IMF Staff Papers 48 (3): 561-592.

Bahl, Roy. 1999. "Fiscal Decentralization as Development Policy." Public Budgeting and Finance 19 (2): 59-75.

Bardhan, Pranab. 2002. "Decentralization of Governance and Development." Journal of Economic Perspectives 16 (4): 185-205.

Besley, Timothy and Stephen Coate. 2003. "Centralized versus Decentralized Provision of Local public Goods: A Political Economy Approach.” Journal of Public Economics 87 (12): 2611-2637.

Bolton, Patrick, and Gerard Roland. 1997. "The Breakup of Nations: A Political EconomyAnalysis.” Quarterly Journal of Economics 112 (4): 1057-1090.

Brancati, Dawn. 2005. "Pawns Take Queen: The Destabilizing Effects of Regional Parties in Europe." Constitutional Political Economy 16 (2): 14-59.

Brancati, Dawn. 2006. "Decentralization: Fueling the Fire or Dampening the Flames of Ethnic Conflict and Secessionism?" International Organization 60 (3): 651-685.

Breuss, Fritz and Markus Eller. 2004. "The Optimal Decentralisation of Government Activity: Normative Recommendations for the European Constitution." Constitutional Political Economy 15 (1): 27-76.

Brusis, M. 2002. "Between EU Requirements, Competitive Politics, and National Traditions: Re-creating Regions in the Accession Countries of Central and Eastern Europe" Governance An International Journal of Policy, Administration and Institutions 15 (4): 531-559.

Council of Europe. 1996-2006. Structure and Operation of Local and Regional Democracy: Forty Country Reports. Strasbourg: Council of Europe. Available online at

http://www.coe.int/t/e/legal_affairs/local_and_regional_democracy/documentation/lib rary/StructureOperation/default.asp\#TopOfPage last accessed October 19, 2007).

Dear, M, Ruth Fincher and Lise Curie. 1977. "Measuring the External Effects of Public Programs." Environment and Planning A 9 (2): 137-147.

De Winter, Lieven and Margarita Gomez-Reino Cachafeiro. 2002. "European Integration and Ethnoregionalist Parties." Party Politics 8 (4): 483-503.

Dinan, Desmond. 2005. Ever Closer Union. An Introduction to European Integration, $3^{\text {rd }}$ ed. Houndmills: Palgrave Macmillan.

Duchacek, Ivo D. 1970. Comparative Federalism. The Territorial Dimension of Politics. New York: Holt, Rhinehart and Winston.

Ederveen, Sjef, Henri L.F. de Groot and Richard Nahuis. 2006. "Fertile Soil for Structural Funds? A Panel Data Analysis of the Condtitional Effectiveness of European Cohesion Policy." Kyklos 59 (1): 17-42.

Eshet, Tzipi, Mira G. Baron, Mordechai Shechter and Ofira Ayalon. 2007. "Measuring Externalities of Waste Transfer Stations in Israel Using Hedonic Pricing." Waste Management 27 (5): 614-625. 
Fearon, James D. 2003. "Ethnic and Cultural Diversity by Country." Journal of Economic Growth 8 (2): 195-222.

Heston, Alan, Robert Summers and Bettina Aten. 2006. Penn World Table Version 6.2. Center for International Comparisons of Production, Income and Prices at the University of Pennsylvania, September 2006. Available online at: http://pwt.econ.upenn.edu (last accessed September 19, 2007).

Hoehler, Fred K. 2000. "Bias and Prevalence Effects on Kappa Viewed in Terms of Sensitivity and Specificity." Journal of Clinical Epidemiology 53 (5): 499-503.

Hooghe, Liesbet ed. 1996. Cohesion Policy and European Integration. Building Multilevel Governance. Oxford: Oxford University Press.

Hooghe, Liesbet and Gary Marks. 2001. Multilevel Governance and European Integration. Lanham: Rowman and Littlefield.

Hooghe, Liesbet and Gary Marks. 2003. "Unraveling the Central State, but How? Types of Multi-level Governance." American Political Science Review 97 (2): 233-243.

Horváth, Tamás M. ed. 2000. Decentralization: Experiments and Reforms, Volume 1. Budapest: Local Government and Public Sector Reform Initiative.

Huber, Evelyn and john D. Stephens. 2001. Development and Crisis of the Welfare State. Parties and Policies in Global Markets. Chicago: The University of Chicago Press.

Irwin, Elena G. and Nancy E. Bockstael. 2001. "The Problem of Identifying Land Use Spillovers: measuring the Effects of Open Space on Residential Property Values." American Journal of Agricultural Economy 83 (3): 698-704.

Janson, Harald and Ulf Olsson. 2001. "A Measure of Agreement for Interval or Nominal Multivariate Observations." Educational and Psychological Measurement 61 (2): 277-289.

Jeffery, Charlie. 2000. "Subnational Mobilization and European Integration: Does it Make Any Difference?” Journal of Common Market Studies 38 (1): 1-23.

Jolly, Seth. 2006. A Europe of Regions? Regional Integration, Subnational Mobilization and the Optimal Size of States. Durham: Duke University.

Jolly, Seth. 2007. "How the EU Fuels Subnational Regionalism." Working Paper. Available online at http://www.duke.edu/ skj3/howEUFuels.pdf (last accessed May 1, 2008).

Kandeva, Emilia ed. 2001. Stabilization of Local Governments. Local Governments in Central and Eastern Europe. Volume 2. Budapest: Local Government and Public Sector Reform Initiative.

Keating, Michael. 1998. The New Regionalism in Western Europe. Territorial Restructuring and Political Change. Aldershot: Edward Elgar.

Le Goffe, Philippe. 2000. "Hedonic Pricing of Agriculture and Forestry Externalities." Environmental and Resource Economics 15 (4): 397-401.

Lipsky, Michael. 1983. Street Level Bureaucracy. Dilemmas of the Individual in Public Services. New York: Russell Sage Foundation.

Long, J. Scott. 1997. Regression Models for Categorical and Limited Dependent Variables. London: Sage Publications

Loughlin, John with the collaboration of Eliseo Aja, Udo Bullman, Frank Hendriks, Anders Lidström and Daniel-L. Seiler. 2001. Subnational Democracy in the European Union. Challenges and Opportunities. Oxford: Oxford University Press.

Marks, Gary and Liesbet Hooghe. 2000. "Optimality and Authority: A Critique of Neoclassical Theory." Journal of Common Market Studies 38 (5): 795-816.

Marks, Gary, Jane Salk, Leonard Ray and François Nielson. 1996. "Competences, Cracks and Conflicts: Regional Mobilization in the European Union." Comparative Political Studies 29 (2): 164-192. 
Marshall, Monty G. and Keith Jaggers. 2004. Polity IV Data Set. [Computer file; version p4v2004]. College Park: Center for International Development and Conflict Management, University of Maryland. Available online at: http://www.cidcm.umd.edu/polity (last accessed September 19, 2007).

Martinez-Vazquez, Jorge and Robert M. McNab. 2003. "Fiscal Decentralization and Economic Growth." World Development 31 (9): 1597-1616.

Meyers, Marcia K., and Susan Vorsanger. 2003. "Street-Level Bureaucrats and the Implementation of Public Policy." In: Handbook of Public Administration, eds. B. Guy Peters and Jon Pierre. London: Sage Publications, 245-254.

Munteanu, Igor, and Victor Popa eds. 2001. Developing New Rules in the Old Environment. Volume 3. Local Governments in the Eastern Europe, in the Caucasus and Central Asia. Budapest: Local Government and Public Service Reform Initiative.

Oates, Wallace E. 1972. Fiscal Federalism. New York; Harcourt Brace Jovanovich.

Oates, Wallace E. 1999. “An Essay on Fiscal Federalism.” Journal of Economic Literature 37 (3): 1120-1149.

Oates, Wallace E. 2005. "Toward a Second-Generation Theory of Fiscal Federalism." International Tax and Public Finance 12 (4): 349-373.

Osterkamp, Riger and Markus Eller. 2003. "Functional Decentralisation of Government Activity." Journal for Institutional Comparisons 1 (3): 36-42.

Page, Edward C. 1991. Localism and Regionalism in Europe. Oxford: Oxford University Press.

Page, Edward C. and Michael Goldsmith. 1987. Central and Local Government Relations. A Comparative Analysis of West European Unitary States. London: Sage Publications.

Prud'homme, Rémy. 1995. "The Dangers of Decentralization.” World Bank Research Observer 10 (2): 201-220.

Rokkan, Stein. 1999. "Cleavage Structures and Party Systems.” In State Formation, Nation-Building, and Mass Politics in Europe. The Theory of Stein Rokkan, eds. Peter Flora, Stein Kuhnle, and Derek Urwin. New York: Oxford University Press, 275-340.

Rokkan, Stein and Derek Urwin. 1983. Economy, Territory, Identity. Politics of West European Peripheries. London: Sage Publications.

Schakel, Arjan H. 2008a. "Understanding Variation in Subnational Regional Authority. A Postfunctionalist Theory of Jurisdictional design," paper presented at the $4^{\text {th }}$ Transatlantic Dialogue held at Bocconi University, Milan, Italy, June 12-14, 2008.

Schakel, Arjan H. 2008a. "Validation of the Regional Authority Index" Regional and Federal Studies, 18 (2-3): 143-166.

Scott, Patrick G. 1997. “Assessing Determinants of Bureaucratic Discretion: An Experiment in Street-Level Decision Making." Journal of Public Administration Research and Theory 7 (1): 35-57.

Shah, Anwar. 1997. The Reform of Intergovernmental Fiscal Relation in Developing and Emerging Market Economies. Washington DC: The World Bank.

Shah, Anwar. 2006. "A Comparative Institutional Framework for Responsive, Responsible, and Accountable Local Governance.” In Local Governance in Industrial Countries, ed. Anwar Shah. Washington D.C.: The World Bank, 1-40.

Sharpe, L. Jim ed. 1993. The Rise of Meso Government in Europe. London: Sage Publications.

Sim, Julius and Chris C. Wright. 2005. "The Kappa Statistic in Reliability Studies: Use, Interpretation, and Sample Size Requirements." Physical Therapy 85 (3): 257-268. 
Sowa, Jessica E., and Sally Coleman Selden. 2003. "Administrative Discretion and Active Representation: An Expansion of the Theory of Representative Bureaucracy." Public Administration Review 63 (6): 700-710.

Stegarescu, Dan. 2005. "Costs, Preferences, and Institutions: An Empirical Analysis of the Determinants of Government Decentralization." ZEW Discussion Paper, No. 0539.

Ter-Minassian, Teresa. 1997a. "Intergovernmental Fiscal Relations in a Macroeconomic Perspective: An Overview." In Fiscal Federalism in Theory and Practice, ed. Teresa Ter-Minassian. Washington: International Monetary Fund, 3-24.

Ter-Minassian, Teresa ed. 1997b. Fiscal Federalism in Theory and Practice. Washington: International Monetary Fund.

Thorlakson, Lori. 2003. "Comparing federal institutions: Power and representation in six federations." West European Politics 26(2): 1-22.

Toonen, Theo and Trui Steen. 2008. "Towards a Framework for the Comparative Institutional Analysis of Central-Local Relations. The Netherlands as a Case Example." Paper presented at the $4^{\text {th }}$ Transatlantic Dialogue, June 12-14, 2008, Milan Italy.

Treisman, Daniel. 2002. "Defining and Measuring Decentralization: A Global Perspective." Unpublished Paper, Los Angeles, University of California. Available online at: http://wwsscnet.ucla.edu/polisci/faculty/treisman/defin.pdf (last accessed September 19, 2007).

Treisman, Daniel. 2007. The Architecture of Government: Rethinking Political Decentralization. Cambridge: Cambridge University Press.

Tullock, Gordon. 1969. "Federalism: Problems of Scale." Public Choice 6 (1): 19-29.

Urwin, Derek W. 1985. "The Price of a Kingdom: Territory, Identity and the CentrePeriphey Dimension in Western Europe." In Centre-Periphery Relations in Western Europe, eds. Yves Mény and Vincent Wright. London: George Allen \& Unwin, 151170.

Vanhanen, Tatu. 2000. “A New Dataset for Measuring Democracy, 1810-1998." Journal of Peace Research 37 (2): 251-265. Polyarchy dataset. Version 2.0. [updates until 2000] available onlince at: $h \mathrm{ttp}: / / w w w . p r i o . n o / p a g e / P r o j e c t$ detail//9244/42472.html (last accessed September 19, 2007).

Watts, Ronald L. 2008. Comparing Federal Systems, $3^{\text {rd }}$ ed. Montreal: McGill-Queen's University Press.

Weigher, J.C. and R.H. Zerbst. 1973. "The Externalities of Neighborhood Parks: An Empirical Investigation." Land Economics 49 (1): 99-105.

Wheare, Kenneth C. 1963. Federal Government, $4^{\text {th }}$ ed. Oxford: Oxford University Press. 


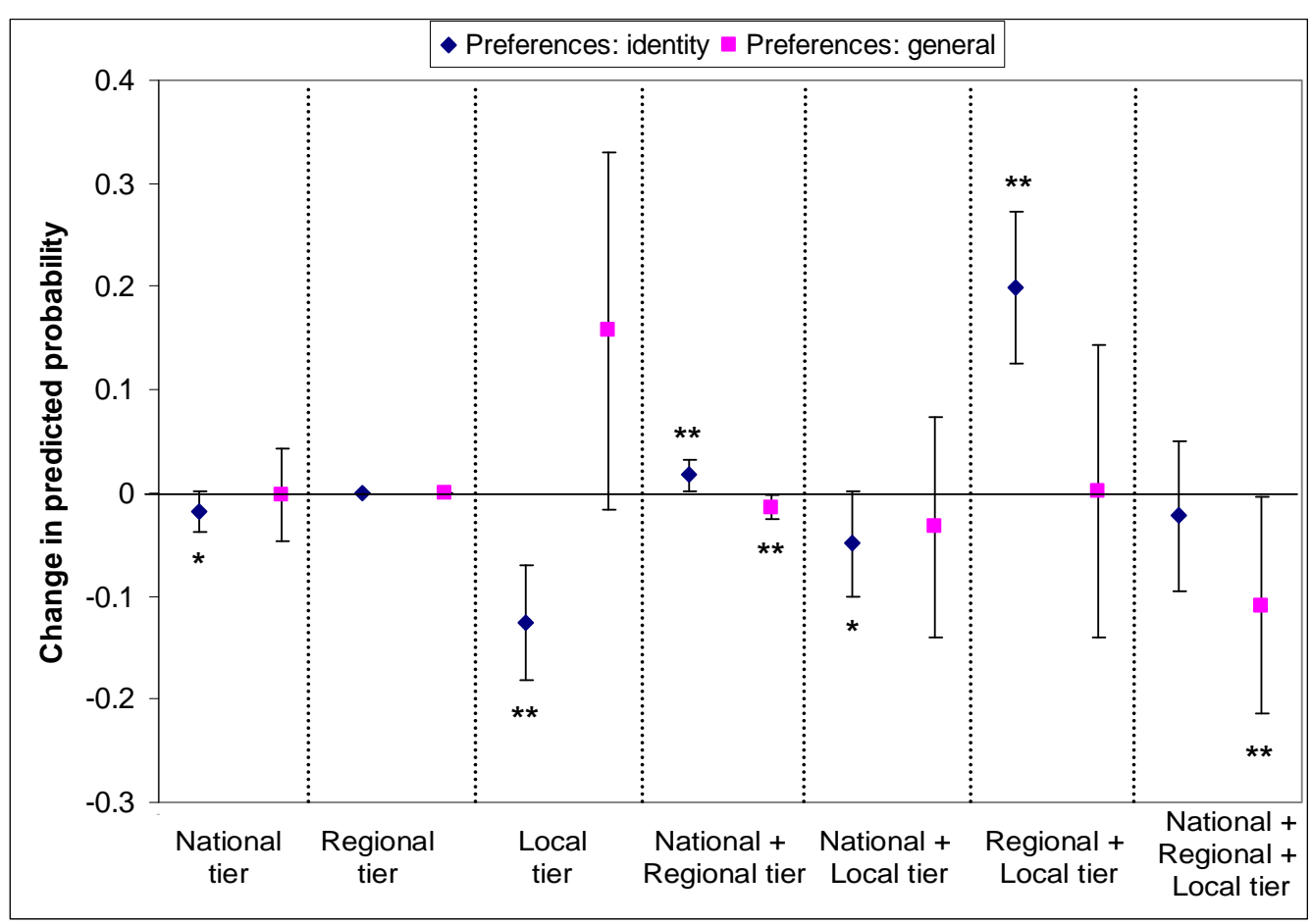

Figure 1. Change in predicted probabilities for policy provision by governmental tiers

Notes: shown are changes in predicted probabilities and their $95 \%$ confidence interval (delta method) for policy provision by seven outcome categories when ethnic fragmentation and strength of ethnoregional parties (preferences: identity) and general preferences (preferences: general) increase with one standard deviation while all other variables are held at their mean.

$* \mathrm{p}<0.05$ (one-tailed)

$* * \mathrm{p}<0.05$ (two-tailed)

The changes in predicted probabilities are based upon the following multinomial model:

$\operatorname{Pr}($ outcome category $)=\quad \beta($ probability National tier $)+\beta($ probability Regional tier $)+$

$\beta$ (probability Local tier $)+\beta$ (ceiling effect $)+$ $\beta($ multilevel $)+\beta$ (ethnic fragmentation $)+\beta$ (strength of ethnoregional parties $)+\beta$ (democratic openness $)+$ $\beta$ (polyarchy $)+\beta$ (economic welfare $)+\beta(E U-$ membership $)+\beta($ EU-subsidies $)+$ constant

Overall model parameters:

$\mathrm{N}=853$ country*policies (26 countries)

Pseudo-likelihood $=-1168.21$

McFadden pseudo- $\mathrm{R}^{2}: 22.0 \%$

Cox\&Snell pseudo- $\mathrm{R}^{2}: 53.8 \%$

See table 2 for the operationalization of the independent variables and table $\mathrm{C} 1$ for descriptive statistics. Estimates are obtained with the prvalue command in Stata. 
Table 1A. Matching of the expert survey and country study data

\begin{tabular}{cccccc}
\hline $\begin{array}{l}\text { Jurisdictional } \\
\text { size }\end{array}$ & Experts & Country A & Country B & Country C & Country D \\
\hline$<20,000$ & 0.1 & Local tier: 1 & & & Local tier: 1 \\
$\pm 100,000$ & 0.1 & & Local tier: 0 & Local tier: 0 & $\begin{array}{c}\text { Regional tier: } \\
0\end{array}$ \\
\pm 1 million & 0.2 & $\begin{array}{c}\text { Regional tier: } \\
1\end{array}$ & $\begin{array}{c}\text { Regional tier: } \\
1\end{array}$ & & National tier: 1 \\
\pm 5 million & 0.4 & National tier: 1 & & & \\
\pm 10 million & 0.2 & & National tier: 1 & National tier: \\
1 & & & \\
\hline Outcome category & NRL =1 & NR $=1$ & $\mathrm{~N}=1$ & $\mathrm{NL}=1$ \\
\hline
\end{tabular}

Table 1B. Resulting data structure of the combined expert survey and country study data

\begin{tabular}{|c|c|c|c|c|c|c|c|c|}
\hline \multirow[t]{2}{*}{ Country } & \multirow[t]{2}{*}{ Policy } & \multirow{2}{*}{$\begin{array}{l}\text { Outcome } \\
\text { category }\end{array}$} & \multicolumn{3}{|c|}{ Probability tier } & \multirow{2}{*}{$\begin{array}{l}\text { Ceiling } \\
\text { effect }\end{array}$} & \multirow{2}{*}{$\begin{array}{l}\text { Multi- } \\
\text { level }\end{array}$} & \multirow{2}{*}{$\begin{array}{c}\text { Other } \\
\text { independent } \\
\text { variables } \rightarrow\end{array}$} \\
\hline & & & Local & Regional & National & & & \\
\hline$A$ & 1 & NRL & 0.1 & 0.2 & 0.4 & 0.2 & 74 & \\
\hline$B$ & 1 & NR & 0.1 & 0.2 & 0.2 & 0.0 & 74 & \\
\hline C & 1 & $\mathrm{~N}$ & 0.1 & - & 0.2 & 0.0 & 74 & \\
\hline$D$ & 1 & $\mathrm{NL}$ & 0.1 & 0.1 & 0.2 & 0.6 & 74 & \\
\hline
\end{tabular}

Notes: the experts indicate the probability that a tier of a given jurisdictional size should have a role in the provision of the policy considering only scale effects and externalities. Outcome category represent policy provision by the: $\mathrm{N}=$ national tier only; $\mathrm{NR}=$ National + Regional tier; $\mathrm{NL}=$ National + Local tier; $\mathrm{NRL}=$ National + Regional + Local tier. 
Table 2. Operationalization of the independent variables

\begin{tabular}{|c|c|c|}
\hline Variable & Operationalization & Source \\
\hline \multicolumn{3}{|l|}{$\begin{array}{l}\text { Functional: externalities } \\
\text { and scale effects }\end{array}$} \\
\hline $\begin{array}{l}\text { Probability National tier } \\
\text { Probability Regional tier } \\
\text { Probability Local tier }\end{array}$ & $\begin{array}{l}\text { Probability that a tier should have a } \\
\text { role according to externalities and } \\
\text { scale effects }\end{array}$ & $\begin{array}{l}\text { Expert survey } \\
\text { (appendix A) }\end{array}$ \\
\hline Ceiling effect & $\begin{array}{l}\text { Sum of the probabilities given by the } \\
\text { experts to jurisdictions which are } \\
\text { above the countries national tier }\end{array}$ & Expert survey \\
\hline Multilevel & $\begin{array}{l}\text { Total number of placed } X^{\prime} \text { 's by the } \\
\text { experts per policy }\end{array}$ & $\begin{array}{l}\text { Expert survey } \\
\text { (appendix A) }\end{array}$ \\
\hline \multicolumn{3}{|l|}{ Preferences } \\
\hline Ethnic fragmentation & $\begin{array}{l}\text { The probability that two randomly } \\
\text { selected individuals belong to a } \\
\text { different ethnic group }\end{array}$ & $\begin{array}{l}\text { Fearon (2003) and } \\
\text { Annett (2001) }\end{array}$ \\
\hline $\begin{array}{l}\text { Strength of ethnoregional } \\
\text { Parties }\end{array}$ & $\begin{array}{l}\text { Percentage of seats for the regional/ } \\
\text { ethnic party in the lower chamber of } \\
\text { parliament } \mathrm{t}^{\mathrm{B}}\end{array}$ & $\begin{array}{l}\text { Schakel }(2008 \mathrm{a}) \\
\text { and the PARLINE } \\
\text { database }\end{array}$ \\
\hline General preferences & $\begin{array}{l}\text { Vanhanen overall index (Competition } \\
\text { multiplied by Participation) }\end{array}$ & Vanhanen (2000) \\
\hline \multicolumn{3}{|l|}{ Controls } \\
\hline $\begin{array}{l}\text { Democracy } \\
\text { Polyarchy }\end{array}$ & $\begin{array}{l}\text { Combined Polity Score (Polity IV) } \\
\text { ranges from }+10 \text { (strongly democratic) } \\
\text { to }-10 \text { (strongly autocratic) }^{\mathrm{C}}\end{array}$ & $\begin{array}{l}\text { Marshall and } \\
\text { Jaggers (2004) }\end{array}$ \\
\hline $\begin{array}{l}\text { Development } \\
\text { Economic welfare }\end{array}$ & Natural log GDP (real) per capita & Heston et al. (2006) \\
\hline $\begin{array}{l}\text { European integration } \\
\text { EU-membership }\end{array}$ & $\begin{array}{l}\text { Dichotomous variable }(1=\text { country } \\
\text { was member of the EU before } 1995)\end{array}$ & Dinan (2005) \\
\hline EU-subsidies & $\begin{array}{l}\text { Average receipt of regional } \\
\text { funds as fraction of } \mathrm{GDP}^{\mathrm{D}}\end{array}$ & $\begin{array}{l}\text { Ederveen et al. } \\
(2006)\end{array}$ \\
\hline
\end{tabular}

Notes: all scores refer to one year between 1996-2001 depending on the country. Descriptive statistics can be consulted in appendix C.

A 36 country scores are taken from Fearon (2003) and scores for Iceland, Luxembourg and Malta are taken from Annett (2001). The Pearson correlation between both measures is 0.928 ( $\mathrm{p}<0.01 ; \mathrm{N}=27$ countries).

${ }^{\mathrm{B}}$ Using the criteria developed by Schakel (2008a) the Caucasian republics Armenia, Azerbaijan, Belarus, Kazakhstan, Moldova, Ukraine and Uzbekistan do not have ethnoregional parties represented in national parliament (1995-2001). The PARLINE database of the Inter-Parliamentary Union (IPU) is available on: http://www.ipu.org/parlinee/parlinesearch.asp (last accessed December 14, 2007).

${ }^{\mathrm{C}}$ The scores for Bosnia and Herzegovina, Malta and Luxembourg are assigned by the author.

${ }^{\mathrm{D}}$ Data refer the situation in 1995 as data for later years are not available. 
Table 3. Explaining policy provision

\begin{tabular}{|c|c|c|c|c|c|c|}
\hline $\begin{array}{c}\text { Policy provision by the } \rightarrow \\
\text { Independent variables } \\
\downarrow\end{array}$ & $\begin{array}{l}\text { Regional } \\
\text { tier }\end{array}$ & $\begin{array}{l}\text { Local } \\
\text { tier }\end{array}$ & $\begin{array}{l}\text { National+ } \\
\text { Regional } \\
\quad \text { tier }\end{array}$ & $\begin{array}{l}\text { National+ } \\
\text { Local } \\
\text { tier }\end{array}$ & $\begin{array}{l}\text { Regional+ } \\
\text { Local } \\
\text { tier }\end{array}$ & $\begin{array}{l}\text { National+ } \\
\text { Regional+ } \\
\text { Local tier }\end{array}$ \\
\hline \multicolumn{7}{|l|}{ Functional } \\
\hline Probability National tier & $-0.63^{*}$ & $-0.65^{*}$ & -0.44 & $-0.37^{\star}$ & $-0.78^{*}$ & $-0.31^{*}$ \\
\hline Probability Regional tier & -0.17 & -0.15 & 0.39 & $-0.44^{*}$ & $-0.50^{*}$ & -0.12 \\
\hline Probability Local tier & 0.10 & $1.37^{*}$ & -0.42 & $0.9^{* *}$ & $0.83^{*}$ & $0.65^{*}$ \\
\hline Ceiling effect & -0.48 & -0.30 & -0.14 & -0.28 & $-0.87^{* *}$ & -0.44 \\
\hline Multilevel & $0.61^{*}$ & $0.62^{*}$ & $0.67^{*}$ & $1.31^{*}$ & $1.09^{*}$ & $1.36^{*}$ \\
\hline \multicolumn{7}{|l|}{ Preferences } \\
\hline Ethnic fragmentation & 1.64 & 0.00 & $0.81^{*}$ & -0.30 & $0.95^{*}$ & 0.45 \\
\hline $\begin{array}{l}\text { Strength of ethnoregional } \\
\text { parties }\end{array}$ & -0.57 & -0.10 & 0.09 & 0.20 & 0.17 & -0.08 \\
\hline General preferences & 1.48 & 0.46 & -0.63 & -0.29 & 0.05 & -0.42 \\
\hline \multicolumn{7}{|l|}{ Country specific } \\
\hline $\begin{array}{l}\text { Democracy } \\
\text { Polyarchy }\end{array}$ & -0.73 & -0.19 & 0.43 & 0.07 & -0.55 & 0.04 \\
\hline $\begin{array}{l}\text { Development } \\
\text { Economic welfare }\end{array}$ & 0.35 & 0.18 & 0.38 & $0.44^{*}$ & 0.64 & 0.64 \\
\hline $\begin{array}{l}\text { EU-integration } \\
\text { EU-membership } \\
\text { EU-subsidies }\end{array}$ & $\begin{array}{l}0.49 \\
-28.4\end{array}$ & $\begin{array}{l}-0.35 \\
-0.26\end{array}$ & $\begin{array}{l}-0.20 \\
0.41^{*}\end{array}$ & $\begin{array}{c}0.09 \\
-0.03\end{array}$ & $\begin{array}{l}-0.03 \\
-0.47\end{array}$ & $\begin{array}{c}-0.17 \\
0.25\end{array}$ \\
\hline Constant & -7.13 & -1.77 & -0.56 & $0.83^{*}$ & $1.40^{*}$ & $1.74^{*}$ \\
\hline
\end{tabular}

Notes: Results of a multinomial logit analysis with the national tier as a base category. The table displays beta coefficients. All independent variables are standardized.

$* \mathrm{p}<0.05$

Overall model parameters:

$\mathrm{N}=853$ country* policies ( 26 countries)

Pseudo-likelihood $=-1168.21$

McFadden pseudo- ${ }^{2}: 22.0 \%$

Cox\&Snell pseudo- $\mathrm{R}^{2}: 53.8 \%$ 
Table 4. Explaining policy provision: number and sign of significant beta coefficients

\begin{tabular}{|c|c|c|c|c|c|c|c|}
\hline $\begin{array}{c}\text { Policy provision by the } \rightarrow \\
\text { Independent variables } \\
\downarrow\end{array}$ & $\begin{array}{l}\text { National } \\
\text { tier }\end{array}$ & $\begin{array}{l}\text { Regional } \\
\text { tier }\end{array}$ & $\begin{array}{c}\text { Local } \\
\text { tier }\end{array}$ & $\begin{array}{l}\text { National+ } \\
\text { Regional } \\
\text { tier }\end{array}$ & $\begin{array}{l}\text { National+ } \\
\text { Local } \\
\text { tier }\end{array}$ & $\begin{array}{l}\text { Regional+ } \\
\text { Local } \\
\text { tier }\end{array}$ & $\begin{array}{l}\text { National+ } \\
\text { Regional+ } \\
\text { Local tier }\end{array}$ \\
\hline \multicolumn{8}{|l|}{ Functional } \\
\hline Probability National tier & +5 & -1 & -2 & - & -1 & -2 & $+2 /-1$ \\
\hline Probability Regional tier & +2 & - & $\begin{array}{c}+1 /- \\
1\end{array}$ & +3 & -2 & -4 & $+1 /$ \\
\hline Probability Local tier & -4 & -4 & +5 & -4 & +3 & $+3 /-1$ & $+3 /-1$ \\
\hline Ceiling effect & +1 & - & +1 & +1 & & -4 & +1 \\
\hline Multilevel & -6 & $+1 /-3$ & $\begin{array}{c}+1 /- \\
3\end{array}$ & $+1 /-2$ & +4 & $+3 /-1$ & +5 \\
\hline \multicolumn{8}{|l|}{ Preferences } \\
\hline Ethnic fragmentation & -2 & +2 & -3 & +3 & -4 & +3 & +1 \\
\hline $\begin{array}{l}\text { Strength of ethnoregional } \\
\text { parties }\end{array}$ & - & -2 & - & +1 & - & +1 & - \\
\hline $\begin{array}{l}\text { General preferences } \\
\text { Country specific }\end{array}$ & - & +3 & +2 & -2 & - & -1 & -2 \\
\hline $\begin{array}{l}\text { Democracy } \\
\text { Polyarchy }\end{array}$ & - & -1 & -1 & +3 & - & - & -1 \\
\hline $\begin{array}{l}\text { Development } \\
\text { Economic welfare }\end{array}$ & -1 & - & -1 & - & +1 & - & +1 \\
\hline $\begin{array}{l}\text { EU-integration } \\
\text { EU-membership } \\
\text { EU-subsidies }\end{array}$ & $\begin{array}{l}- \\
-1\end{array}$ & $\begin{array}{l}- \\
-\end{array}$ & $\begin{array}{l}- \\
-2\end{array}$ & $\begin{array}{l}- \\
+4\end{array}$ & $\begin{array}{l}- \\
-1\end{array}$ & $\begin{array}{l}- \\
-2\end{array}$ & $\begin{array}{l}- \\
+2\end{array}$ \\
\hline
\end{tabular}

Notes: the table displays the number of significant beta coefficients and their sign. Each column represents a run of the same multinomial model but with the outcome category in the column as a base category. Only beta coefficients which are significant at the 5\% level ( $\mathrm{p}<0.05$; clustered corrected standard errors) are included. Beta coefficients which are positive are shown in bold. Out of 504 comparisons $(7 \times 6$ category comparisons x 12 independent variables) 148 beta coefficients are found to be significant at the $5 \%$ level.

Overall model parameters:

$\mathrm{N}=853$ country*policies (26 countries)

Pseudo-likelihood $=-1168.21$

McFadden pseudo- $\mathrm{R}^{2}: 22.0 \%$

Cox\&Snell pseudo- $\mathrm{R}^{2}: 53.8 \%$

Full results can be obtained from the author. 
Table 5. Explaining policy provision: pseudo- $\mathrm{R}^{2}$

\begin{tabular}{lcccc}
\hline \multicolumn{1}{c}{ Cluster } & Cox\&Snell pseudo- $R^{2}$ & $\Delta \mathrm{R}^{2}$ & McFadden pseudo- $\mathrm{R}^{2}$ adj. & $\Delta \mathrm{R}^{2}$ \\
\hline Functional & 36.5 & 36.5 & 10.5 & 10.5 \\
Preferences & 47.6 & 11.0 & 14.8 & 4.3 \\
Democracy & 48.7 & 1.1 & 15.0 & 0.2 \\
Development & 50.2 & 1.5 & 15.4 & 0.4 \\
EU integration & 53.8 & 3.6 & 16.8 & 1.4 \\
\hline
\end{tabular}

Notes: shown are scores for two scalar measures of fit $\left(\mathrm{pseudo}-\mathrm{R}^{2}\right)$ and the difference between the scores by addition of a cluster of independent variables to the multinomial model (from the top to the bottom of the table). The adjusted McFadden's pseudo- $\mathrm{R}^{2}$ adjusts for the number of parameters in the model.

Clusters of independent variables:

Functional probability National tier, probability Regional tier, probability Local tier, ceiling effect and multilevel

Preferences ethnic fragmentation, strength of ethnoregional parties and

Democracy polyarchy

Development economic welfare

EU-integration EU-membership and EU-subsidies

See table 2 for the operationalization of the independent variables and table $\mathrm{C} 1$ for descriptive statistics. The estimates are based upon 853 country*policies ( 26 countries).

Cox \& Snell pseudo $R^{2}=1-\left\{\frac{L\left(M_{\alpha}\right)}{L\left(M_{\beta}\right)}\right\}^{\frac{2}{N}}$

$L\left(M_{\alpha}\right)$ is the likelihood of the model with just the intercept; $L\left(M_{\beta}\right)$ is the likelihood for the model; $N$ is the total number of observations;

McFadden pseudo $R_{\text {adjusted }}^{2}=1-\frac{\ln \hat{L}\left(M_{\beta}\right)-K}{\ln \hat{L}\left(M_{\alpha}\right)}$

$\hat{L}\left(M_{\beta}\right)$ is the estimated likelihood of the model including the independent variables; $\hat{L}\left(M_{\alpha}\right)$ is the estimated likelihood of the mode with just the intercept; $K$ is the number of predictors.

$\Delta \mathrm{R}^{2}=$ difference in pseudo- $\mathrm{R}^{2}$ when a cluster of hypotheses is added to the model.

Estimates are obtained with the fitstat command in Stata. 


\section{Appendix A \\ Expert Survey $^{11}$}

The functional variables used in the analysis in this article are based upon an expert survey conducted in January-March 2006 by Hooghe, Marks and Schakel. The experts were obtained from the member list of the Organized Section Federalism and Intergovernmental Relations of the American Political Science Association and of the European Group of Public Administration. The section and EGPA organizes members with an interest in federalism, intergovernmental relations and state and local government. Thirty-six out of 120 experts (response rate 30\%) were asked to evaluate the externalities and scale effects for 34 policies. All experts were academics at American (30) or European (6) universities.

The 34 policies were taken from the country studies performed by the Council of Europe (1996-2000) and the Local Government and Public Reform Initiative (Horváth 2000; Kandeva 2001; Munteanu and Popa 2001) to establish congruence with the country policy provision dataset (see appendix B). The question wording for each of the 34 policies was as follows:

"Please place yourself in the role of a public policy analyst and put an $\mathrm{X}$ in the boxes [jurisdiction] that best fit your evaluation of what levels of government are most efficient in providing the policy in question. We would like you to give your judgment abstracting from the particulars of any country (i.e. whether a policy is actually provided in a particular country). Also the question of which level of government funds the policy is a separate topic and should not affect your judgments in this survey. By efficiency, we refer to 1) economic externalities and 2) scale economies."

The question was followed by a definition of scale effects and economic externalities.

"Economic externalities are the positive or negative economic effects of a policy for individuals in other jurisdictions. Efficient policy should encompass the people economically affected by the policy. For example, defense policy protects all those who live in a country, while street cleaning affects only those in a particular locality.

Scale economies refer to the decreased cost of policy provision per unit as the scale of provision increases. Efficient policy should reap the available economies of scale for providing a policy. Defense policy is most efficient when a single army deters threats to all those who live in a country, while street cleaning can be efficiently organized at a local level."

The expert was allowed to put an $X$ in five jurisdictions (boxes) with assigned population sizes (based upon average population sizes of the jurisdictions classified in the Nomenclature of Territorial Units for Statistics (NUTS) and Local Administrative Unit (LAU) used by the European Union):

$\begin{array}{ll}\text { Local } & <20,000 \\ \text { Local-Regional } & \pm 100,000 \\ \text { Regional } & \pm 1 \text { million } \\ \text { Regional-National } & \pm 5 \text { million } \\ \text { National } & >10 \text { million }\end{array}$

\footnotetext{
${ }^{11}$ The survey was pre-tested by Professor Deil Wright and by William Ewell at the University of North Carolina, Chapel Hill. The conductors are deeply grateful for their feedback on the survey. Professor Wright facilitated the distribution among APSA-federalism members; Professor G. Bouckaert arranged for the survey to be sent to EGPA members.
} 
The experts were allowed to put an $X$ in more than one jurisdiction to allow for the possibility that some policies are efficiently handled at multiple scales. A list of policies is provided in table A1. This table also provides the scores for the multilevel variable used in the analysis.

Table A1. List of 34 policies used in the expert survey

\begin{tabular}{lc}
\hline \multicolumn{1}{c}{ Policy } & Multilevel \\
\hline roads (including local roads to highways) & 101 \\
transport (including rail transport, subways/metro, buses) & 99 \\
environmental protection (including air, water, soil) & 95 \\
health protection (e.g. disease prevention) & 86 \\
water supply & 83 \\
tourism promotion & 83 \\
Museums & 82 \\
sewage and water treatment & 79 \\
public housing & 78 \\
family welfare services (e.g. homeless shelters/families in crisis) & 77 \\
secondary education & 77 \\
parks and open spaces & 76 \\
primary education & 73 \\
vocational and technical education & 73 \\
Electricity & 71 \\
welfare homes (e.g. orphanages) & 71 \\
sport and leisure facilities & 71 \\
Libraries & 70 \\
In-home services for the elderly and the handicapped & 70 \\
voter registration & 69 \\
theatre and concert facilities & 69 \\
Hospitals & 69 \\
Gas & 68 \\
regional/spatial planning & 68 \\
town planning & 68 \\
refuse collection & 66 \\
refuse disposal & 65 \\
higher education & 64 \\
pre-school education & 62 \\
consumer protection & 61 \\
nursery and kindergarten & 59 \\
fire protection & 58 \\
district heating (public distribution of hot water) & 53 \\
cemeteries and crematoria & 47 \\
\hline Nots: Malilevel is measured by the toalnumber ofplaced & \\
\hline
\end{tabular}

Notes: Multilevel is measured by the total number of placed $X$ 's by all experts for a given policy; high values indicate that the policy should be provided by multiple governmental tiers when only externalities and scale effects are considered; low values indicate that a jurisdiction of a particular population size should provide the policy. 


\section{Inter-expert reliability}

We use the Cronbach's alpha ${ }^{12}$ for each jurisdiction and all jurisdictions combined to measure reliability among expert evaluations. From table A2 one may conclude that the experts converge.

Table A2. Cronbach's alpha scores per jurisdiction

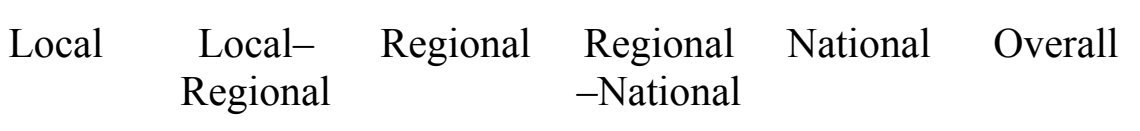

\begin{tabular}{lllllll}
\hline Cronbach's $\alpha$ & 0.890 & 0.743 & 0.843 & 0.834 & 0.913 & 0.872 \\
\hline
\end{tabular}

Notes: results for 34 experts (two experts had to be excluded as they had too many missing data) over 34 policies (listwise deletion).

\section{Structural error}

Two different versions of the expert survey were sent to the experts. Version A presented the 34 policies in the order as they appeared in the country studies mentioned above $(\mathrm{N}=14)$. Version B presented the 34 policies in alphabetical order $(\mathrm{N}=22)$. The presence of systematic error due to the presentation of the list of policies can be gauged by comparing the answers of the experts for both versions of the expert survey. An one-way ANOVA analysis for each policy reveals that 9 out of 170 possible comparisons ( 34 policies $\mathrm{x} 5$ jurisdictions) are significantly different between the two versions (that is $5 \%$ ). This leads to the conclusion that, overall, there are no significant differences between the two versions of the expert survey and that there is no systematic error due to the listing of the policies.

Another structural bias may result from the fact that most consulted experts work at an university in the United States of America (the country, however, is not included in the analysis). It might be that their country experience (partly) framed their answers to the question which jurisdiction should provide a policy. We cannot discern whether this is the case but we may argue to what extent this has implications for the findings. The results are based upon differences between policy provision by tiers as functional theory would have it against actual policy provision in countries. If the experts used their country experience in their answers than the benchmark is biased and does not reflect optimal policy provision according to scale effects and externalities. Rather, the deviations refer to a difference in policy provision between the United States and another country. In spite of this, the conclusions remain the same; that is, when, for example, ethnic fragmentation rises it leads to a higher probability that the regional tier is involved in policy provision compared to the state level in the United States. The results, however, are either under- or overestimations compared to a functional

\footnotetext{
12 Other reliability measures appropriate for nominal data such as Cohen's/Fleiss' kappa and iota (Janson and Olsson 2001) can not be applied to the expert survey. First, the data suffer from the prevalence problem of zeros. If prevalence is high, chance agreement is also high and Cohen's/Fleiss' kappa and iota are reduced accordingly (Sim and Wright 2005). Prevalence adjusted kappa indices exist but Hoehler (2000) is critical of the use of the prevalence-adjusted-kappa because he believes that the effect of prevalence on the magnitude of kappa is itself informative and should not be adjusted for. Second, experts were allowed to place an $\mathrm{X}$ in more than one answer category. This fact violates the assumption of mutually exclusive and exhaustive categories underlying the iota and Cohen's/Fleiss' kappa. Third, one should weigh Cohen/Fleiss' kappa and iota according to the degree of disagreement between experts but this is not possible for this expert survey due to the non-exclusiveness of categories. There are good theoretical reasons for non-exclusiveness because some policies are more efficiently and effectively provided when several governmental levels play a role in policy provision.
} 
benchmark. As the United States is a rather decentralized country, compared to the countries in our analysis, underestimation is more likely than overestimation.

\section{Funding of policies}

It is important to note that the experts were asked to discard the question which level of government should fund the policies (see question wording above). Spillovers benefits across jurisdictions arising from local policy provision "can be promoted by appropriate unit subsidies which might encourage decentralized authorities to extend outputs to efficient levels" (Oates 2005, 352). Internalizing externalities constitutes, therefore, not a necessary condition for optimal policy provision. The exclusion of the question which level of government should finance the policy or which level of government should have which tax powers (Oates 2005) does not need to concerns us as I am interested in explaining local and regional policy provision and not whether and how optimal levels of policy output are being reached.

\section{Validation}

The expert survey on externalities and scale effects of 34 policies is, to our knowledge, the first one of its kind. Therefore, it is difficult to validate the data. Alesina, Angeloni amd Schuknecht (2005) compare their normative assessment of the desirable allocation of policy responsibilities between the European Union and member states with public opinion data (Eurobarometer). Unfortunately, public opinion data on the desired allocation of policy provision tasks between national and subnational tiers for the countries included in this analysis do not exist. To tentatively validate the data I use Shah's (1997) assessment on assigning responsibilities for local public services. Anwar Shah is an economist, coordinator of the public sector reform cluster at the World Bank and has advised many governments on fiscal federalism issues. For several policies he provides "a subjective assessment of how various allocative criteria favor either local or metropolitan assignment" (1997: 21). Shah uses economies of scale, economies of scope, benefit-cost spillout, political proximity and consumer sovereignty as allocative criteria which (partly) overlap with the criteria used by the experts during their assessment. Based on his evaluation Shah comes up with a categorization of policies: local public services that could be decentralization to (1) all local governments, (2) to larger urban municipalities and (3) to metropolitan or regional governments (1997: 22-24). What makes Shah's analysis informative is that he gives approximate population sizes for larger urban municipalities and metropolitan or regional governments which coincide with the population size assigned to the jurisdictions Local-Regional (approx. 100,000 people) and Regional (approx. 1 million people) in the expert survey.

In table A3 we compare Shah's analysis with the expert survey for 19 policies. The first two columns give the policy labels as used by Shah and the expert survey. The next columns represent the proportion of experts which placed an $X$ in that jurisdictional category (each expert is given a weight of one). Figures in bold indicate that a majority of experts agree with Shah whereas underlined figures indicate that a majority of experts places an $\mathrm{X}$ in another jurisdiction.

As can be seen in table A3, the experts and Shah agree on the first five policies. A majority of the experts place an $X$ in the local jurisdiction $(<20,000)$ for policies which, according to Shah, should be decentralized to all local governments. This is also the case for policies which could be decentralized to larger urban municipalities (population over 100,000). Most experts place an X in the jurisdiction Local-Regional $(100,000)$ except for land use planning. However, in the latter case there is a 
difference in label use between the expert survey and Shah which might indicate that they refer to different policies. Shah makes a distinction between 'land use planning' and 'regional planning' whereas the experts only assessed 'regional and spatial planning'.

There is also convergence between the experts and Shah for policies which, according to Shah, could be provided by metropolitan or regional governments (combined population of one million). Again, a difference in label use might explain disagreements. Shah use the labels 'neighborhood parks and recreation', 'regional parks', 'local libraries' and 'special libraries' whereas the experts were asked to evaluate 'parks and open spaces' and 'libraries' without further differentiation. Therefore, it is not surprising that the experts are somewhat evenly divided over the three smallest jurisdictions (i.e. Local, Local-Regional and Regional) for these two policies. The difference in label use might also explain the disagreement between Shah and the experts for 'public health'/'health protection'. The experts and Shah also diverge in their judgment for 'hospitals' and 'air and water pollution'/'environmental protection', though a second largest majority of the experts placed an $\mathrm{X}$ in a jurisdiction next to the preferred population size by Shah. Overall, Shah and the experts agree to a large extent and this we find comforting. 
Table A3. Comparison between Shah (1997) and the expert survey on the question which jurisdiction should provide the policy for 19 policies.

\begin{tabular}{|c|c|c|c|c|c|c|}
\hline & & & Jurisdictional & zes as used & in the expert survey & \\
\hline $\begin{array}{c}\text { Policy label used } \\
\text { by Shah (1997) }\end{array}$ & $\begin{array}{l}\text { Policy label used } \\
\text { in the expert survey }\end{array}$ & $\begin{array}{c}\quad \text { Local } \\
<20,000\end{array}$ & $\begin{array}{l}\text { Local-Regional } \\
\quad \pm 100,000\end{array}$ & $\begin{array}{l}\text { Regional } \\
\pm 1 \text { million }\end{array}$ & $\begin{array}{l}\text { Regional-National } \\
\pm 5 \text { million }\end{array}$ & $\begin{array}{c}\text { National } \\
>10 \text { million }\end{array}$ \\
\hline
\end{tabular}

Local public services that could be decentralized to all local governments according to Shah (1997)

$\begin{array}{lllllll}\text { Fire protection } & \text { Fire protection } & 0.52 & 0.27 & 0.14 & 0.01 & 0.06 \\ \text { Primary education } & \text { Primary education } & 0.34 & \underline{0.36} & 0.14 & 0.09 & 0.07 \\ \text { Refuse collection } & \text { Refuse collection } & 0.45 & 0.26 & 0.16 & 0.08 & 0.05 \\ \text { Neighborhood parks and recreation } & \text { Parks and open spaces } & 0.39 & 0.26 & 0.25 & 0.06 & 0.04 \\ \text { Local libraries } & \text { Libraries } & 0.29 & 0.29 & 0.28 & 0.07 & 0.06\end{array}$

Local public services that could be decentralized to larger urban municipalities (population over 100,000) according to Shah (1997)

$\begin{array}{lllllll}\text { Land use planning } & \text { Regional/spatial planning } & 0.05 & 0.24 & \underline{0.40} & 0.24 & 0.07 \\ \text { Secondary education } & \text { Secondary education } & 0.21 & 0.37 & 0.23 & 0.07 & 0.12\end{array}$

Local public services to be provided by metropolitan or regional governments (combined population of one million) according to Shah (1997)

$\begin{array}{lllllll}\text { Air and water pollution } & \text { Environmental protection } & 0.10 & 0.14 & 0.18 & \underline{0.32} & 0.27 \\ \text { Electric power } & \text { Electricity } & 0.12 & 0.17 & 0.37 & 0.22 & 0.13 \\ \text { Gas } & \text { Gas } & 0.19 & 0.20 & 0.31 & 0.16 & 0.14 \\ \text { Hospitals } & \text { Hospitals } & 0.07 & \underline{0.39} & 0.24 & 0.21 & 0.09 \\ \text { Public health } & \text { Health protection } & 0.09 & 0.16 & 0.19 & 0.22 & \underline{0.34} \\ \text { Refuse disposal } & \text { Refuse disposal } & 0.23 & 0.24 & 0.29 & 0.16 & 0.08 \\ \text { Regional parks } & \text { Parks and open spaces } & \underline{0.39} & 0.26 & 0.25 & 0.06 & 0.04 \\ \text { Regional planning. } & \text { Regional/spatial planning } & 0.05 & 0.24 & 0.40 & 0.24 & 0.07 \\ \text { Sewage disposal } & \text { Sewage and water treatment } & 0.19 & 0.29 & 0.32 & 0.13 & 0.07 \\ \text { Special libraries } & \text { Libraries } & \underline{0.29} & \underline{0.29} & 0.28 & 0.07 & 0.06 \\ \text { Transportation } & \text { Transport } & 0.08 & 0.19 & 0.31 & 0.26 & 0.16 \\ \text { Water supply } & \text { Water supply } & 0.22 & 0.22 & 0.30 & 0.17 & 0.09\end{array}$

Notes: The figures represent the proportion of experts which placed an X in that jurisdictional category (each expert is given a weight of 1). Figures in bold represent agreement whereas underlined figures represent disagreement between Shah (1997) and a majority of the experts. 


\section{Appendix B \\ Country Data}

The Council of Europe (CoE) has published 32 country studies on the structure and operation of local and regional democracy (Council of Europe 1996-2000). Twentyseven country studies contain a table which shows which tiers are competent for the provision of 47 policies. Representatives from the ministries in charge of local and regional government represented the country in the CDLR (The Steering Committee on Local and Regional Democracy of the Council of Europe) and they completed/filled in the tables (pers.comm. Montgomery). These tables also indicate the type of competence, i.e. whether the tier of government has exclusive, shared, compulsory, or discretionary competence, and the exercise of the competence (direct, indirect, in own right, of for another authority). Since the definitions may not have been consistently applied across countries (pers.comm. Montgomery), I have chosen not use this information.

The Local Government and Public Service Reform Initiative (LGI) conducted country studies in Eastern and Central European Countries and in several former Russian Republics (Horváth 2000; Kandeva 2001; Munteanu and Popa 2001). The set-up of the country studies and the information contained within the country studies is broadly similar to that of the CoE. Twenty-three country studies present tables which score for 44 policies whether a governmental tier has a role in policy provision.

The country studies provide data on actual policy provision per tier for a total of 40 countries (16 West European, 15 Central and Eastern European and 9 Caucasian republics) and 34 policies common to both surveys (see table A1). Ten countries are analyzed by both sources (Bulgaria, Croatia, Czech Republic, Estonia, Latvia, Lithuania, Macedonia, Poland, Romania and Slovakia). To enhance comparability, the Council of Europe data for these ten countries are used since the $\mathrm{CoE}$ dataset is the source of most countries. The results presented in this article do not significantly change when data from the LGI country studies are used instead of the CoE data.

\section{Three-tier versus two-tier countries}

The decision whether to decentralize policy provision is highly dependent on the number of subnational tiers. When a policy is best provided by a regional tier but a country has no regional tier, the government has to decide whether to provide the policy at the national or local level or to provide it at both levels. However, in a three-tier country the policy can be provided at the regional level. This means that the possible choices regarding which tiers should provide a policy differ in three-tier versus two-tier countries. In order to account for this, the dataset is split up in two databases. One database refers 14 twotier countries. These are: Armenia, Azerbaijan, Bulgaria, Cyprus, Czech Republic, Estonia, Iceland, Luxembourg, Macedonia, Malta, Portugal, Slovakia, Slovenia and Turkey.

The second database refers to 26 three-tier countries and these are: Albania, Austria, Belarus, Belgium, Bosnia and Herzegovina, Croatia, Denmark, Finland, France, Greece, Hungary, Kazakhstan, Latvia, Lithuania, Moldova, the Netherlands, Norway, Poland, Romania, Russian federation, Serbia and Montenegro, Spain, Sweden, Switzerland, Ukraine and Uzbekistan. 
Five of these three-tier countries have actually four governmental tiers (i.e. Belgium, Bosnia and Herzegovina, France, Spain, and Poland). There are several reasons why these countries are not analyzed separately. First, in these countries there are fifteen possible combinations of governmental tiers which may provide a policy (i.e. $N, R_{1}, R_{2}$, $\mathrm{L}, \mathrm{NR}_{1}, \mathrm{NR}_{2}, \mathrm{NL}, \mathrm{R}_{1} \mathrm{R}_{2}, \mathrm{R}_{1} \mathrm{~L}, \mathrm{R}_{2} \mathrm{~L}, \mathrm{NR}_{1} \mathrm{R}_{2} \mathrm{~L}, \mathrm{NR}_{1} \mathrm{R}_{2}, \mathrm{NR}_{1} \mathrm{~L}, \mathrm{NR}_{2} \mathrm{~L}, \mathrm{R}_{1} \mathrm{R}_{2} \mathrm{~L}$ ). Some of the categories are empty-that is, policy provision is never provided by a specific combination-and multinomial models cannot be estimated when certain categories do not have observations.

Second, because policies are embedded in countries the number of 'true' observations in a statistical sense is far closer to five than to 170 ( 5 countries times 34 policies) which makes the likelihood that one finds statistical significant results rather low. Furthermore, a low number of cases will give rise to estimation difficulties due to multicollinearity between the independent variables. For these reasons, the four-tier countries are included in the three-tier country database by taking the data for the most authoritative intermediate tier while disregarding data of the less authoritative intermediate tier. The results appear to be robust when data for the less authoritative tier is included.

\section{Selection bias}

The policies examined in the surveys are not randomly selected. They are policies where it is conceivable that subnational tiers may play a role. This is why the dataset does not contain policies that tend to be exclusively provided by the national tier, for example defense, foreign relations and justice. Hence one should be aware of a potential selection bias in the data, though it has to be said that a large number of selected policies involve the national government as policy provider: 42 percent of combinations in three-tier countries, and 75 percent in two-tier countries (see table B1). If there is a selection bias it is not likely to be severe.

Table B1. Frequency of policy provision by government tiers in three- and two-tier countries

\begin{tabular}{ccccc}
\hline \multirow{2}{*}{ Policy provision by the } & \multicolumn{2}{c}{ Three-tier countries } & \multicolumn{2}{c}{ Two-tier countries } \\
& Frequency & Percentage & Frequency & Percentage \\
\hline National tier only & 60 & 7.0 & 114 & 24.9 \\
Regional tier only & 55 & 6.5 & - & - \\
Local tier only & 239 & 28.0 & 110 & 24.0 \\
National+Regional tier & 39 & 4.6 & - & - \\
National+Local tier & 84 & 9.9 & 234 & 51.1 \\
Regional+Local tier & 199 & 23.3 & - & - \\
National+Regional+Local tier & 177 & 20.8 & - & - \\
\hline Total & 853 & $100 \%$ & 458 & $100 \%$
\end{tabular}

Notes: The frequency data refer to country*policies. Policy provision is measured for 34 policies in 26 three-tier and 14 two-tier countries and refers to one year between 1996-2001. 


\section{Validation}

The country data are new in its kind. To my knowledge, there does not exist another quantifiable and broadly comparative list of policies provided by governmental tiers. Thorlakson $(2003,6-11)$ develops a numerical index of federal jurisdiction for six federations; it measures the proportion of policy areas of exclusive state jurisdiction compared to areas of concurrent, shared and exclusive federal jurisdiction. Alesina, Angeloni and Schuknecht $(2005,279)$ measure the policy involvement of the European Union-but not the member states-by counting "the number of legal, judiciary and other, non-binding acts emanating from the European Union". Most often, scholars use subnational expenditure data as a proxy for subnational policy involvement-despite the caveats associated with these indicators (see Schakel 2008b). In order to gauge the validity of the dependent variable I compare the dependent variable with subnational expenditure data. To this purpose I need to re-operationalize the country data. I follow the approach taken by Alesina, Angeloni and Schuknecht (2005) and count the number of policies for which the national tier is responsible (i.e. N, NR, NL and NRL). Subsequently, I calculate the proportion of policies for which the national tier is involved out of the total number of policies. Figure B1 plots this measure against the percentage of subnational expenditure out of total government expenditure.

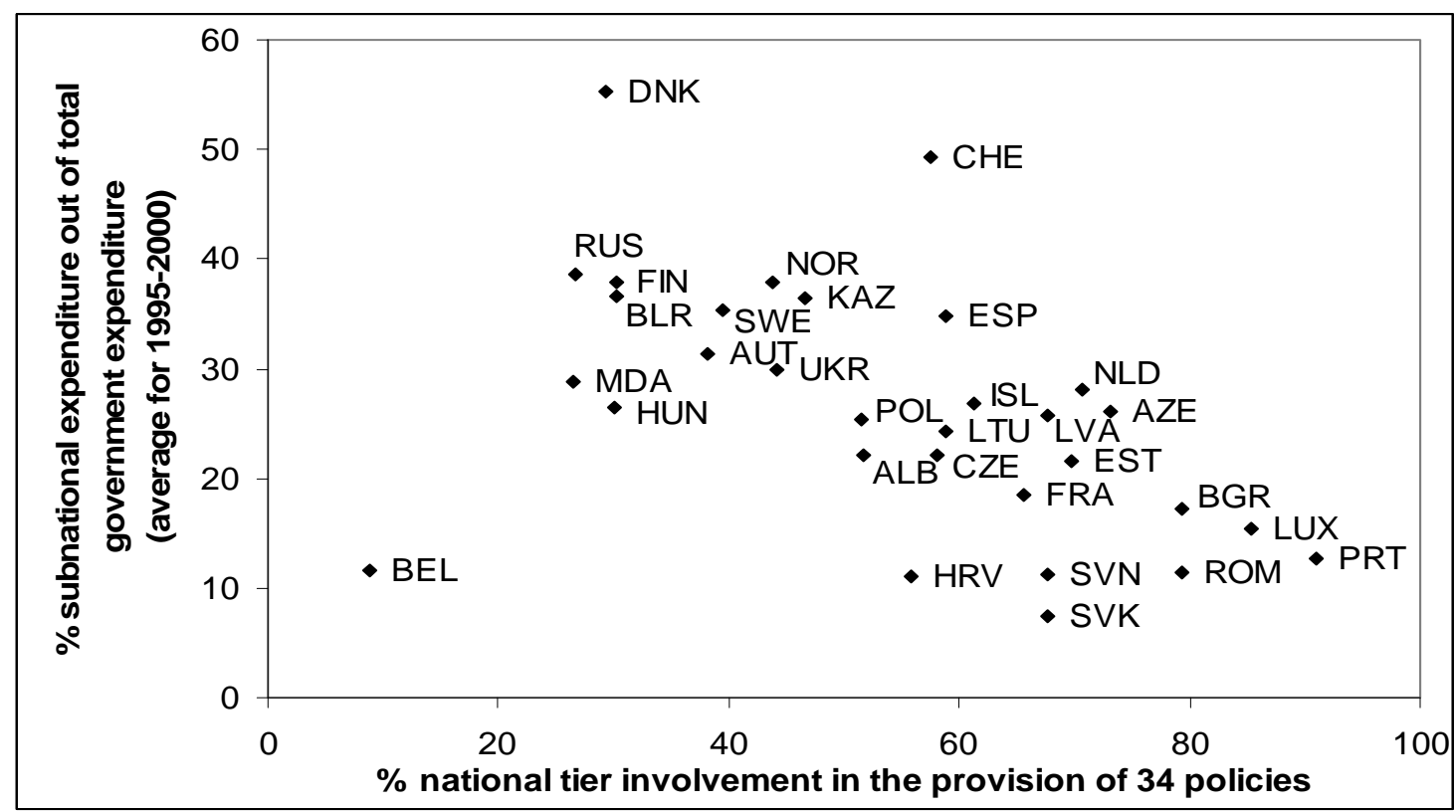

Figure B1. National tier involvement in the provision of 34 policies (in percentage) plotted against the percentage subnational expenditure out of total government expenditure (average for 1995-2000) for 31 countries

Notes: $\mathrm{ALB}=$ Albania; AUT $=$ Austria; $\mathrm{AZE}=$ Azerbaijan; $\mathrm{BEL}=$ Belgium; $\mathrm{BGR}=$ Bulgaria; $\mathrm{BLR}=$ Belarus; $\mathrm{CHE}=$ Switzerland; $\mathrm{CZE}=$ Czech Republic; DNK = Denmark; ESP $=$ Spain; EST = Estonia; FIN $=$ Finland FRA $=$ France; HRV $=$ Croatia HUN $=$ Hungary; ISL = Iceland; KAZ = Kazakhstan; LTU = Lithuania; LVA = Latvia; LUX = Luxembourg; MDA = Moldova; NLD = the Netherlands; NOR = Norway; $\mathrm{POL}=$ Poland; $\mathrm{PRT}=$ Portugal; $\mathrm{ROM}=$ Romania; $\mathrm{RUS}=$ Russian federation; $\mathrm{SVK}=$ Slovakia; $\mathrm{SVN}=$ Slovenia; $\mathrm{SWE}=$ Sweden; UKR $=$ Ukraine.

Source: World Bank (2006) 
As expected, national tier involvement in policies is negatively correlated with subnational expenditure (Pearson $r:-0.50, \mathrm{p}<0.01, \mathrm{~N}=31$ ). Belgium is a clear outlier. This can be explained by a difference in timing of the policy decentralization and fiscal decentralization. The constitutional revision of 1993, which devolved competencies to the regions and communities, came into effect in 1995 but fiscal arrangements were only significantly revised in favor of regions and communities in 2001 (Swenden 2006). The measure for policy provision dates from 1997 and so falls between the two reforms. If Belgium is excluded the Pearson correlation is: $-0.67(\mathrm{p}<0.01, \mathrm{~N}=30)$. 


\section{Appendix C \\ Descriptive Tables}

Table C1. Descriptive statistics of the independent variables for the three-tier and two-tier country dataset

\begin{tabular}{l|ccc|ccc}
\hline Independent Variables & \multicolumn{3}{|c|}{ Three-tier countries } & \multicolumn{3}{c}{ Two-tier countries } \\
& Mean & Std. deviation & Min-Max & Mean & Std. deviation & Min - Max \\
\hline Probability National tier & 0.135 & 0.107 & $0.01-0.61$ & 0.187 & 0.115 & $0.01-0.61$ \\
Probability Regional tier & 0.239 & 0.095 & $0.01-0.53$ & - & - & - \\
Probability Local tier & 0.251 & 0.145 & $0.02-0.53$ & 0.251 & 0.151 & $0.03-0.53$ \\
Ceiling effect & 0.057 & 0.113 & $0.00-0.81$ & 0.198 & 0.230 & $0.00-0.93$ \\
Multilevel & 72.50 & 11.55 & $47-101$ & 72.82 & 11.21 & $47-101$ \\
Ethnic fragmentation & 0.335 & 0.202 & $0.047-0.681$ & 0.261 & 0.152 & $0.03-0.535$ \\
Strength ethnic/regional party & 3.250 & 8.111 & $0.00-40.48$ & 3.454 & 6.079 & $0.00-20.00$ \\
Democratic openness & 27.483 & 10.818 & $0.19-42.03$ & 29.746 & 9.345 & $6.87-43.62$ \\
Polyarchy & 5.661 & 6.298 & $-9-10$ & 7.633 & 4.009 & $-7-10$ \\
Economic welfare & 9.174 & 0.815 & $7.659-10.177$ & 9.225 & 0.696 & $8.055-10.514$ \\
EU-membership & 0.239 & 0.425 & $0-1$ & 0.146 & 0.354 & $0-1$ \\
EU-subsidies & 0.062 & 0.220 & $0.00-1.078$ & 0.111 & 0.382 & $0.00-1.480$ \\
\hline
\end{tabular}

Notes: data refer to 853 country*policies (26 countries) for three-tier countries and to 458 country*policies (14 countries) for two-tier countries. 
Table C2. Pearson correlations between the independent variables for the three-tier and two-tier country dataset

\begin{tabular}{|c|c|c|c|c|c|c|c|c|c|c|c|c|c|}
\hline & Independent Variables & 1 & 2 & 3 & 4 & 5 & 6 & 7 & 8 & 9 & 10 & 11 & 12 \\
\hline 1 & Probability National tier & - & - & $-0.36^{*}$ & $0.34^{*}$ & -0.05 & 0.08 & -0.04 & 0.03 & $0.20^{*}$ & $0.22^{*}$ & 0.00 & -0.15 \\
\hline 2 & Probability Regional tier & $-0.23^{*}$ & - & - & - & - & - & - & - & - & - & - & - \\
\hline 3 & Probability Local tier & $-0.49^{*}$ & $-0.09^{*}$ & - & $-0.38^{*}$ & 0.02 & -0.00 & -0.01 & -0.04 & -0.05 & -0.01 & -0.01 & -0.01 \\
\hline 4 & Ceiling effect & $0.25^{*}$ & $-0.21^{*}$ & $-0.25^{\star}$ & - & -0.05 & -0.08 & $-0.16^{*}$ & $0.14^{*}$ & $0.29 *$ & $0.28^{*}$ & $0.10^{*}$ & $-0.23^{*}$ \\
\hline 5 & Multilevel & $0.28^{*}$ & $0.08^{*}$ & $-0.54^{*}$ & $0.11^{*}$ & - & -0.01 & 0.01 & 0.03 & 0.03 & 0.02 & -0.00 & -0.00 \\
\hline 6 & Ethnic fragmentation & 0.07 & $-0.13^{*}$ & 0.01 & $0.10^{*}$ & -0.00 & - & $0.57^{*}$ & $-0.15^{\star}$ & -0.09 & $0.09^{*}$ & $-0.24^{*}$ & $-0.40^{*}$ \\
\hline 7 & Strength of ethnoregional parties & -0.02 & $-0.07^{*}$ & 0.00 & 0.06 & 0.00 & $0.40^{*}$ & - & -0.01 & 0.03 & -0.00 & $-0.24^{*}$ & $-0.17^{*}$ \\
\hline 8 & Democratic openness & 0.02 & -0.03 & -0.01 & -0.03 & -0.00 & $-0.39^{*}$ & $0.11^{*}$ & - & $0.80^{*}$ & $0.53^{*}$ & 0.06 & 0.00 \\
\hline 9 & Polyarchy & 0.04 & $0.08^{*}$ & -0.01 & $0.11^{*}$ & -0.00 & $-0.47^{*}$ & $-0.11^{*}$ & $0.78^{*}$ & - & $0.43^{*}$ & $0.24^{*}$ & $0.17^{*}$ \\
\hline 10 & Economic welfare & -0.05 & 0.04 & -0.01 & -0.08 & -0.01 & $-0.42^{*}$ & $-0.25^{*}$ & $0.59^{*}$ & $0.56^{*}$ & - & $0.29^{*}$ & $0.13^{*}$ \\
\hline 11 & EU-membership & -0.06 & -0.06 & -0.01 & $-0.18^{*}$ & -0.01 & $-0.19^{*}$ & 0.01 & $0.53^{*}$ & $0.37^{*}$ & $0.50^{*}$ & - & $0.70^{*}$ \\
\hline 12 & EU-subsidies & -0.04 & 0.02 & -0.00 & $-0.14^{*}$ & -0.00 & $-0.21^{*}$ & -0.03 & $0.24^{*}$ & $0.19^{*}$ & $0.15^{*}$ & $0.38^{*}$ & - \\
\hline
\end{tabular}

Notes: Pearson correlations for the three-tier country dataset $(\mathrm{N}=853)$ are shown below the diagonal and the Pearson correlations for the two-tier country dataset $(\mathrm{N}=453)$ are shown above the diagonal.

$* \mathrm{p}<0.05$ 